\title{
Sergio Grez Toso*
}

\author{
Un ePisodio de las Políticas del “Tercer Período” de la

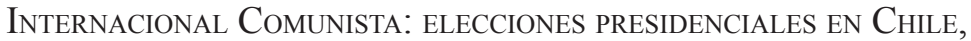 \\ $1931^{* *}$
}

\begin{abstract}
RESUMEN
En este artículo explicamos como incidieron las políticas de "clase contra clase", inspiradas en los análisis del "Tercer Período" de la Internacional Comunista, en la postulación de dos candidaturas comunistas rivales en las elecciones presidenciales chilenas de 1931 .

El autor examina los programas, la campaña y los resultados electorales obtenidos por Elías Lafertte (candidato del Partido Comunista de Chile "oficial" apoyado por el Buró Sudamericano de la Internacional Comunista) y por Manuel Hidalgo (candidato del Partido Comunista de Chile de "oposición").
\end{abstract}

Palabras claves: Chile, siglo xx, comunismo, Internacional Comunista, "Tercer Período", elecciones presidenciales, política de "clase contra clase".

\begin{abstract}
This article explains how the "class against class" policies, inspired by "Third Period" analysis from the Communist International, had a bearing on the nomination of two rival Communist candidates in the Chilean presidential elections of 1931.

The author examines the political programs, campaigns and the election results obtained by Elías Lafertte (candidate of the "official" Communist Party of Chile and backed by the South American Bureau of the Communist International) and Manuel Hidalgo (candidate of the "opposing" Chilean Communist Party).
\end{abstract}

Key words: Chile, twentieth century, Communism, Communist International, "Third Period", presidential elections, "class vs. class" politics

Recibido: Marzo 2015.

Aceptado: Agosto 2015.

\footnotetext{
* Dr. en Historia, académico de la Universidad de Chile. Correo electrónico: sergiogreztoso@gmail.com

** Artículo elaborado en el marco del proyecto FONDECYT Nº1130286 de la Comisión Nacional de Investigación Científica y Tecnológica de Chile (CONICYT). El autor agradece la colaboración de Ximena Urtubia Odekerken.
} 


\section{INTRODUCCIÓN}

El conocimiento acerca de la trayectoria histórica del comunismo chileno ha experimentado significativos avances en las últimas décadas. La publicación de numerosos trabajos académicos rigurosos y sólidamente documentados ha permitido progresar en la superación de la literatura "de combate", tanto aleccionadora y hagiográfica como de "leyenda negra" anticomunista que prevaleció durante mucho tiempo. Los estudios a los que hacemos referencia no solo se han beneficiado de las nuevas orientaciones y metodologías de la historiografía actual sino, también, de la creciente profesionalización del "oficio" de historiador'. Otro factor que ha estimulado este progreso ha sido la "revolución de los archivos" que sucedió a la "caída de los muros", gracias a la apertura de repositorios en la ex Unión Soviética, en particular los de la Internacional Comunista (Komintern) o III Internacional, que están contribuyendo a develar muchos fenómenos que permanecían en la penumbra y sobre los cuales, hasta fines del siglo xx, solo era posible intuir de un modo difuso sus contornos y proyecciones. En lo referido a Chile, la compilación y publicación de la documentación depositada en los archivos de la Komintern realizada por Olga Ulianova y Alfredo Riquelme, sumada a otras fuentes encontradas en otros archivos nacionales e internacionales, están aportando un material de invaluable riqueza que estimula la producción historiográfica ${ }^{2}$.

La apertura de los repertorios soviéticos en particular, ha permitido profundizar el conocimiento sobre las relaciones entre el Partido Comunista de Chile (PCCh) y la Internacional Comunista. Uno de los pasajes de la historia del comunismo chileno que más se ha beneficiado con estos descubrimientos documentales, ha sido el relacionado con la "bolchevización" de este partido inducida por el Secretariado Sudamericano

${ }^{1}$ Por razones de espacio no es posible dar cuenta detallada de la numerosa bibliografía disponible relacionada con el tema. No obstante, los textos señalados a continuación trazan balances historiográficos que, en su conjunto, son exhaustivos: Jorge Rojas Flores, "Historia, historiadores y comunistas chilenos", en Manuel Loyola y Jorge Rojas (compiladores), Por un rojo amanecer: hacia una historia de los comunistas chilenos, Santiago, Impresora Valus 2000, pp. 1-79; Rolando Álvarez Vallejos, "Historia, historiografía y memorias del comunismo chileno en la primera década del siglo xxI. Un ensayo bibliográfico", prólogo del libro de Viviana Bravo Vargas, ;Con la Razón y la Fuerza, Venceremos! La Rebelión Popular y la Subjetividad Comunista en los '80, Santiago, Ariadna Ediciones, 2010, pp. 11-30; Olga Ulianova, "El comunismo chileno a través de los archivos soviéticos", en Augusto Varas, Alfredo Riquelme y Marcelo Casals (editores), El Partido Comunista en Chile. Una historia presente, Santiago, Catalonia/Universidad de Santiago de Chile/FLACSO Chile, 2010, pp. 261-287; Sergio Grez Toso, Introducción del libro Historia del comunismo en Chile. La era de Recabarren (1912-1924), Santiago, LOM Ediciones, 2011, pp. 7-20. Véanse, además, las siguientes obras colectivas: Olga Ulianova, Manuel Loyola y Rolando Álvarez (editores), 1912-2012. El siglo de los comunistas chilenos, Santiago, Universidad de Santiago de Chile, Instituto de Estudios Avanzados, 2012. Al final de este libro se encuentra un anexo sobre "Fuentes y bibliografía para el estudio del Partido Comunista de Chile" de gran utilidad para los investigadores; Manuel Loyola y Rolando Álvarez (editores), Un trébol de cuatro hojas. Las Juventudes Comunistas de Chile en el siglo Xx, Santiago, Ariadna/América en Movimiento, 2014.

${ }^{2}$ Olga Ulianova y Alfredo Riquelme Segovia (editores), Chile en los archivos soviéticos 1922-1991, Tomo 1: Komintern y Chile 1922-1931, Santiago, Ediciones de la Dirección de Bibliotecas, Archivos y Museos, Centro de Investigaciones Diego Barros Arana, colección Fuentes para Historia de la República/ LOM Ediciones/Universidad de Santiago de Chile, 2005, vol. xxIII Tomo 2: Komintern y Chile 1931-1935, Santiago, Ediciones de la Dirección de Bibliotecas, Archivos y Museos, Centro de Investigaciones Diego Barros Arana, colección Fuentes para Historia de la República/LOM Ediciones, 2009, vol. xxx. 
(SSA), luego Buró Sudamericano (BSA) de la Komintern, a fines de las décadas de 1920 y comienzos de 1930 respectivamente, en especial durante los años en que prevalecieron en el centro dirigente mundial del comunismo internacional las políticas sectarias de "clase contra clase", derivadas de los análisis del llamado "tercer período" de desarrollo del capitalismo mundial después del término de la Primera Guerra Mundial.

Los estudios monográficos y reinterpretaciones de estos fragmentos de la historia del comunismo chileno han abarcado temas tan variados como la lucha fraccional al interior del partido, la intervención directa del SSA/BSA en dichos acontecimientos, el efecto de las políticas de "clase contra clase" en ciertas coyunturas como la insurrección de la marinería (septiembre de 1931), la "Pascua Trágica" de Copiapó y Vallenar (diciembre de 1931), la efímera "República Socialista" (1932) o el levantamiento indígena y campesino de Ranquil en la zona del Alto Biobío (1934). No obstante estos avances, quedan aún episodios prácticamente inexplorados desde los cuales se pueden observar los efectos de estas políticas en Chile. Uno de ellos, al que memorialistas e historiadores han prestado escasa atención, es el referido a la presentación de dos candidaturas comunistas rivales en las elecciones presidenciales de octubre de 1931, pocos meses después de producida la caída de la dictadura del coronel Carlos Ibáñez del Campo ${ }^{3}$.

En este trabajo pretendemos aportar al conocimiento de las consecuencias de las políticas resultantes de los análisis del "tercer período", en particular las relacionadas con el nivel y alcance de las alianzas que los comunistas debían practicar, realizando para ello una indagación a la luz de las candidaturas concurrentes en dichas elecciones: la de Elías Lafertte, representando al PCCh "oficial", sostenido por el SSA de la Komintern, versus la de Manuel Hidalgo, abanderado del PCCh "de oposición”, purgado y execrado por la oficina regional de la Internacional Comunista.

\section{Los primeros debates y formulaciones de la política de Frente Único Proletario EN LA INTERNACIONAL COMUNISTA}

Las políticas de Frente Único de la Internacional Comunista sufrieron sucesivos cambios y generaron intensos debates en el centro del comunismo mundial y en la mayoría de sus partidos miembros. Esta táctica fue planteada por primera vez después del triunfo bolchevique en la guerra civil rusa, cuando se empezó a anunciar el reflujo

${ }^{3}$ Un ejemplo de la exigua o nula atención prestada por los especialistas a la participación comunista en las elecciones presidenciales de 1931, es el estudio de Luis Durán referido a la trayectoria electoral del PCCh. Este trabajo, acucioso respecto de muchas otras coyunturas, ignora casi por completo el tema que nos interesa, limitándose a señalar, en menos de tres líneas de una nota de pie de página, que el PCCh "en el bienio 1931-1932 postuló la candidatura presidencial de Elías Lafertte en dos oportunidades, la primera en octubre de 1931, logrando 2.434 votos, que representaron el $0,86 \%$ de la votación total, y la segunda un año después cuando obtuvo 4.128 sufragios y el 1,2\% a nivel nacional". El autor no menciona la existencia de otra candidatura comunista -la de Manuel Hidalgo- presentada por su fracción, como se sabe, bajo la misma denominación que la postulación de Elías Lafertte: PCCh (sección chilena de la Internacional Comunista): Luis Durán B., "Visión cuantitativa de la trayectoria electoral del Partido Comunista de Chile: 1903-1973", en Augusto Varas, Alfredo Riquelme y Marcelo Casals (editores), El Partido Comunista en Chile. Una historia presente, Santiago, Catalonia/Universidad de Santiago de Chile/FLACSO Chile, 2010, p. 231. 
de los movimientos revolucionarios en Europa y, por consiguiente, se produjo una contraofensiva capitalista destinada a recortar o anular las conquistas que los trabajadores habían obtenido en los primeros años de la Primera pos Guerra Mundial. Considerando que la posibilidad de revoluciones victoriosas se alejaba, especialmente en Alemania, país en el que los bolcheviques habían puesto sus mayores esperanzas, el pleno del Comité Ejecutivo de la III Internacional realizado en diciembre de 1921 aprobó las primeras tesis sobre el Frente Único Proletario. Inspirada en la fórmula de Lenin, "hay que terminar con los asaltos y pasar al asedio", la Komintern diseñó una estrategia de más largo plazo destinada a oponer un frente unido a las ofensivas patronales y estatales en los países europeos. De acuerdo con la nueva línea, se hicieron llamados a los socialdemócratas y a los dirigentes sindicales reformistas, a fin de implementar políticas de frente único proletario para resistir las ofensivas del capital. Este abrupto giro táctico -cambio de una política de ruptura y violentas polémicas con los socialdemócratas a fin de poner en pie un movimiento alternativo (comunista) que aspiraba a hegemonizar la lucha del proletariado mundial, por una política de colaboración con los, hasta entonces, denostados reformistas- produjo mucha confusión y acaloradas polémicas en las jóvenes organizaciones integrantes o simpatizantes de la Komintern. En Berlín, a comienzos de abril de 1922, una conferencia reunió a representantes de la II Internacional (socialdemócrata), de la III Internacional (comunista) y de la II y media Internacional (suerte de efímera posición centrista entre las anteriores). Los resultados de este encuentro fueron magros, ya que, como destacaban los jefes socialdemócratas y reformistas, existía una contradicción fundamental en el planteamiento de los bolcheviques y sus partidarios, al pretender unirse con ellos para combatir a los capitalistas y, al mismo tiempo, denunciarlos como traidores a los intereses del proletariado. Por otra parte, la exigencia socialdemócrata -los bolcheviques debían cesar su política represiva contra las corrientes socialistas opositoras (mencheviques y otras) aliadas o cercanas a las internacionales reformistas- se alzó como un obstáculo insuperable que hizo sucumbir esta primera tentativa de frente único proletario. Lenin (Vladímir Ilich Uliánov) y el Comité Ejecutivo de la Komintern consideraron inaceptables dichas pretensiones, por lo que decidieron que sus representantes debían abandonar el comité conjunto conformado por los delegados de las otras internacionales. En consecuencia, el IV Congreso de la Internacional Comunista, reunido a fines de 1922, no volvió a insistir en esta política pese a que el reciente ascenso del fascismo en Italia sonó como campanada de alerta para el movimiento obrero mundial ${ }^{4}$.

El V Congreso de la Komintern realizado en Moscú en junio-julio de 1924, pocos meses después de la muerte de Lenin, dio los primeros pasos para imponer el modelo bolchevique en todos los partidos comunistas del orbe. Uno de los elementos centrales de la reestructuración implicaba la reconstrucción orgánica de las "secciones nacio-

\footnotetext{
${ }^{4}$ Annie Kriegel, "La III ${ }^{\mathrm{e}}$ Internationale", en Jacques Droz (sous la diréction), Histoire générale du socialisme. 3. De 1918 à 1945, Paris, Quadrige / Presses Universitaires de France, 1997, pp. 80-82; Fernando Claudín, La crisis del movimiento comunista, Barcelona, Ruedo Ibérico, 1977, tomo I: De la Komintern al Kominform, pp. 111-117; "4 4 e Congrès de l'Internationale Communiste. Thèses sur l'unité du front prolétarien", en Thèses, manifestes et résolutions adoptés par les $I^{e r}, I I^{e}, I I I^{e}$ et $I V^{e}$ Congrès de L'Internationale Communiste, Montréal, Québec, Canada, Bibliothèque Communiste/Librairie du Travail, 1919, pp. 160-164.
} 
nales" sobre la base de células de empresa o unidades de producción, en lugar de la organización barrial existente hasta entonces. El control de la Internacional sobre sus partidos se vio reforzado al establecerse el derecho del Comité Ejecutivo de la Komintern a anular o modificar las resoluciones de los órganos directivos y de los congresos de los partidos. Asimismo, se instituyó la aprobación de los programas por parte del centro directivo mundial; también se dio la facultad a ese organismo para expulsar partidos, grupos y militantes que infringieran tanto el programa como los estatutos de la Internacional. Paralelamente, este congreso consagró un repliegue sectario al concluir que el fracaso de una nueva tentativa revolucionaria en Alemania, en 1923, había sido el resultado del "oportunismo de derecha" expresado en políticas de frente único. La socialdemocracia fue identificada como una de las caras del fascismo, razón por la cual, aseguraban los jefes komintereanos, jamás podría ser aliada segura del proletariado en la lucha contra dicha corriente. "Los fascistas - sostuvo Grigori Zinóviev, a la sazón presidente de la Internacional Comunista- son la mano derecha de la burguesía y los socialdemócratas la mano izquierda". De acuerdo con estas ideas, la táctica del frente único proletario quedó reducida en las resoluciones de este Congreso a un "simple medio de agitar y movilizar a las masas", descartándose de hecho la posibilidad de llegar a acuerdos con los partidos socialdemócratas. El frente único debía, en consecuencia, aplicarse solo "por abajo" y los llamamientos a la unidad de acción formulados en dirección de los jefes socialistas y reformistas fueron meras tácticas destinadas a "desenmascararlos" ante los trabajadores. Esta política se saldó con una serie de desaciertos de los partidos afiliados a la III Internacional: en Alemania el partido sufrió una merma de casi un millón de votantes en las elecciones parlamentarias de diciembre de 1924 y sus militantes en los consejos de empresa disminuyeron en un 20\%, en Polonia los comunistas perdieron influencia en el movimiento sindical, en Estonia fracasó un levantamiento en diciembre de 1924 y en Bulgaria el partido incurrió en actos de terrorismo individual que provocaron una oleada de terror blanco y una cuantiosa pérdida de votos propios y de sus aliados. Estos hechos llevaron a varios dirigentes de la Komintern a reevaluar su política en 1925, logrando introducir en la práctica de algunos de sus partidos europeos una inflexión a la línea "izquierdista" preconizada por el V Congreso. Cada giro táctico -en la mayoría de las ocasiones articulado con la evolución de las luchas internas por el poder en el Partido Comunista soviético- provocaba ácidas polémicas, escisiones, rupturas y expulsiones de militantes que discrepaban de las nuevas orientaciones. En ocasiones, las medidas disciplinarias eran decididas por los sectores hegemónicos de los partidos atravesados por estas polémicas, pero en otras circunstancias eran ordenadas directamente por la Internacional, prefigurando, de este modo, un centralismo y autoritarismo que se exacerbaría con el correr del tiempos.

\footnotetext{
${ }^{5}$ Claudín, op. cit., pp. 117-120; Milos Hájek, Historia de la Tercera Internacional, Barcelona, Editorial Crítica, 1984, pp. 117-170; Olga Ulianova, "Cuando los archivos hablaron (Evolución de la estructura organizativa, de la doctrina y línea política del Komintern a partir de sus archivos”, en Ulianova y Riquelme (editores), op. cit, tomo 1, pp. 34-37.
} 


\section{"Clase contra clase": Las políticas del "Tercer Período” de la Internacional Comunista}

Hacia 1927 diversos factores, tales como la estabilización económica europea, el trágico fracaso de las tácticas de frente unido en China y la lucha por el poder en el seno del Partido Comunista y del Estado soviético, dieron como resultado un repentino cambio de tácticas a partir del Sexto Congreso de la Internacional Comunista realizado en Moscú entre el 17 de julio y el 1 de septiembre de 1928.

Nikolái Bujarin (cuya alianza con Iósif Stalin empezaba a desmoronarse debido a la ruda campaña desarrollada en su contra por la mayoría stalinista del Politburó soviético) anunció que estaba comenzando un "tercer período" de desarrollo económico capitalista de posguerra, caracterizado por crisis económicas aceleradas, radicalización de las masas trabajadoras, agudización del conflicto de clases y guerras imperialistas que conllevarían un ataque armado a la Unión Soviética. La crisis por venir, vaticinaba Bujarin, podría culminar en el colapso definitivo del capitalismo. Los partidos comunistas debían, por tanto, prepararse para luchas decisivas, acerándose, superando sus debilidades y alcanzando la hegemonía en el movimiento obrero de sus respectivos países. Ni colaboración ni pactos con los socialdemócratas ni con otros reformistas eran posibles, puesto que ante una situación revolucionaria, dichos sectores revelarían su carácter de servidores del capitalismo y de "socialfascistas" o mano izquierda de la burguesía. Los comunistas tenían que denunciarlos y abocarse a eliminar completamente la influencia que aún ejercían sobre la clase obrera. Solo la táctica de "frente unido desde abajo" (con exclusión absoluta del "frente unido por arriba") era permitida a los comunistas del mundo entero ${ }^{6}$.

La línea "izquierdista" de "clase contra clase" resultante de este congreso tuvo como principales elementos: la tesis sobre el "socialfascismo" que, como hemos visto, ya había estado presente en años anteriores en ciertas formulaciones de los líderes de la Internacional Comunista; la definición del ala izquierda de la socialdemocracia como más peligrosa que la derecha e, incluso, el fascismo; la concepción del frente único solo como colaboración individual con obreros socialistas o, a lo sumo, con algunos grupos de base; el rechazo sistemático de todas las propuestas de las cúpulas socialdemócratas y, en excepcionales ocasiones, la admisión de acuerdos con sus organizaciones de base. Si bien Stalin apoyó esta línea de repliegue sectario -apoyo que resultó decisivo justo en el momento en que el georgiano se imponía en la Unión Soviética frente a sus rivales Lev Trotsky, Grigori Zinóviev y Lev Kámenev- es preciso señalar, como lo hace el historiador Milos Hájek, que tal política había crecido de manera autónoma en la Internacional y que el nuevo hombre fuerte del Partido Comunista de la Unión Soviética (PCUS) se decidió a sostenerla cuando vio que en los partidos comunistas europeos existían fuertes corrientes a su favor?

${ }^{6}$ Hájek, op. cit., pp. 208-209; Ulianova, “Cuando los archivos...”, op. cit., pp. 48-51. La expresión teórica de esta política en el plano de la lucha sindical se encuentra desarrollada en Tesis y resoluciones del $V$ Congreso de la I.S.R., Moscú, septiembre de 1930, Paris, Maison des Syndicats, Pequeña Biblioteca de la Internacional Sindical Roja, sin fecha.

${ }^{7}$ Hájek, op. cit., p. 209. 
La política de "clase contra clase" descartaba, de hecho, toda posibilidad de desarrollar un frente único proletario contra las ofensivas capitalistas. Ni siquiera permitía la conclusión de alianzas tácticas con socialistas o reformistas para frenar el avance del nazismo y del fascismo. Se trataba tan solo -sostiene la historiadora Annie Kriegel- de "una técnica de presentación de la política comunista contra "todas las fracciones de la burguesía', entre ellas la socialdemocracia", puesto que la calidad de partidos obreros era negada a los partidos socialistas, bautizados "socialfascistas". En esta perspectiva, el "frente único" era solo una táctica que apuntaba a separar a los obreros socialdemócratas "equivocados de buena fe", de los líderes socialdemócratas, presentados como "viles servidores de los imperialistas" por la propaganda komintereana ${ }^{8}$. Fortaleciendo esta postura intransigente, en 1931 el Comité Ejecutivo de la Internacional Comunista definió a la socialdemocracia como "principal sostén social de la dictadura burguesa" que desde la revolución rusa se encontraba en incesante evolución hacia el fascismo, y llamó una vez más a los comunistas a desenmascararla para liberar a las masas de su influencia como condición indispensable para que el proletariado pudiera dar una lucha eficaz de liberación del yugo capitalista9 ${ }^{9}$.

Los resultados de la táctica "clase contra clase" fueron desastrosos: en todos los países de Europa en que fue aplicada al pie de la letra se acentuaron las divisiones en el seno del movimiento obrero, mientras que las fuerzas más conservadoras y reaccionarias lograron importantes avances. En Alemania, donde esta política fue implementada de la manera más rigurosa, las polémicas y enfrentamientos entre socialistas y comunistas y, sobre todo, una cerrada política de no colaboración, facilitó la llegada de Adolf Hitler y el Partido Nazi al poder a comienzos de 1933. Ello, pese a que ambos partidos obreros sumaban más votos que los nacionalsocialistas y contaban con formaciones de choque que habrían podido enfrentar en forma conjunta a las bandas hitlerianas de las S.A. y S.S. Los únicos avances reales del movimiento comunista internacional durante los años de la táctica de "clase contra clase" derivada de los análisis del "tercer período" (1928-1934), se produjeron en nuevas áreas geográficas, en países coloniales o dependientes, como los del sudeste asiático, en el Cercano Oriente y en América Latina, lugares en los cuales, con posterioridad, los comunistas serían capaces de resistir la represión y representar, mediante sus ideas y acción, un papel destacado en las luchas anticoloniales y de liberación nacional ${ }^{10}$.

\footnotetext{
${ }^{8}$ Kriegel, op. cit., p. 96.

9 "Las tareas de las secciones de la Internacional Comunista en relación con la agravación de la crisis económica y la maduración, en una serie de países, de las condiciones preliminares de una crisis revolucionaria", en Boletín del Buró Sudamericano de la Internacional Comunista, $\mathrm{N}^{\circ} 19$ y N $\mathrm{N}^{\circ}$, Buenos Aires, julio de 1931, pp. 5-6. Cursivas en el original.

${ }^{10}$ Puesto que la exposición de las consecuencias de la política de "clase contra clase" en diversos países europeos escapa a los objetivos de este trabajo, remitimos al lector a las siguientes obras: Hájek, op. cit., pp. 208-255; Kriegel, op. cit., pp. 92-100; Claudín, op. cit., pp. 121-134; Serge Wolikow, “Aux origines de la galaxie communiste: 1'Internationale", in Dreyfus, Groppo, et al. (sous la direction de), Le siècle des communismes, 2ème. éd., Paris, Éditions de l’Atelier/Éditions Ouvrières, 2004, pp. 306-310; Ulianova, “Cuando los archivos...", op. cit., pp. 56-59.
} 


\section{LA Dictadura de CARLOS IbÁÑEZ \\ Y LA APLICACIÓN DE LAS POLÍTICAS DEL “TERCER PERÍODO” EN CHILE}

En febrero de 1927, el coronel Carlos Ibáñez del Campo, utilizando su privilegiada condición de militar, Comandante en Jefe del Cuerpo de Carabineros y ministro del Interior, en un contexto de acelerada descomposición del sistema político chileno, dio un "golpe blando" que en pocos meses lo catapultó al cargo de Presidente de la República. Luego de desatar una represión sin precedentes contra comunistas, anarquistas y líderes obreros reacios a someterse a las reglas del sindicalismo legal que las fuerzas reformistas burguesas venían imponiendo desde 1924, se elevó a la Presidencia por medio de una elección controlada en la que fue candidato único, ya que su oponente nominal, el líder obrero comunista Elías Lafertte, se encontraba confinado en una isla por orden del propio Ministro-Coronel ${ }^{11}$.

Su dictadura (1927-1931) fue sui generis. Si bien reprimió duramente a sus opositores, en especial a anarquistas, comunistas y sindicalistas de diversas tendencias y también coartó -aunque de manera menos brutal- a opositores burgueses de diversos partidos, su gobierno no se orientó por la tradicional política conservadora de la oligarquía chilena, sino por una mezcla de variadas concepciones e influencias, entre ellas el corporatismo. Se trató de un régimen reformista burgués con marcados rasgos populistas que intentó superar la crisis estructural del modelo exportador monoproductor y del Estado oligárquico que había comenzado a derrumbarse. Encabezó un proceso de profunda modernización y reorganización del Estado: fusionó las distintas policías en el Cuerpo de Carabineros de Chile; impulsó importantes planes de obras públicas; creó la Caja de Crédito Minero, el Instituto de Crédito Industrial, la Dirección de Bibliotecas, Archivos y Museos, la Fuerza Aérea de Chile, la Línea Aérea Nacional (aviación civil) y la Contraloría General de la República, entre otras instituciones ${ }^{12}$.

La política ibañista iba acompañada de un discurso crítico respecto de "los políticos", del parlamentarismo y de la oligarquía, además de promesas de reforma social que le granjearon muchos apoyos entre las clases medias y populares durante los primeros años de su administración. Connotados líderes anarcosindicalistas y comunistas fueron seducidos por el proyecto de Carlos Ibáñez y se pasaron a su campo apenas dio su golpe. La mayoría de los parlamentarios del PCCh proclamó su adhesión al dictador ${ }^{13}$, lo mismo ocurrió con casi todos los congresales y los principales dirigentes del Partido Democrático, amén de otros apoyos que el caudillo militar obtuvo en todos los partidos ${ }^{14}$.

\footnotetext{
${ }^{11}$ Elías Lafertte, Vida de un comunista (Páginas autobiográficas), Santiago, Empresa Editora Austral, 1971, pp. 188-208.

${ }_{12}$ Sobre este gobierno, véase Gonzalo Vial Correa, Historia de Chile (1891-1973), Santiago, Empresa Editora Zig-Zag, 1996, vol. iv; Patricio Bermedo, "Prosperidad económica bajo Carlos Ibáñez del Campo 19271929. La dimensión internacional de un programa económico de gobierno”, en Historia, N2 24, Santiago, 1989.

${ }^{13}$ Vial, op. cit., vol. IV, p. 132. Véase también la declaración de los parlamentarios comunistas Pedro Reyes y Juan Luis Carmona en "Nuestra explicación a los comunistas del país", en La Nación, Santiago, 9 de marzo de 1927.

${ }^{14}$ Sobre el apoyo demócrata a Carlos Ibáñez, véase Sergio Grez Toso, Historia del Partido Democrático de Chile. Auge y ocaso de una organización política popular (1887-1927), capítulo xI: Hacia la dictadura y el ocaso (1925-1927) (en prensa).
} 
Desarrolló una estrategia diferenciada frente al movimiento obrero y popular: reprimió con energía a las corrientes revolucionarias (anarquistas y comunistas) que actuaban en su seno, pero en forma paralela desplegó una estrategia populista de seducción en dirección de mutualistas, sindicalistas y trabajadores dispuestos a acatar las normas del sindicalismo legal, la legislación social y el Código del Trabajo promulgado a fines de su gobierno, cuerpo legal en el que se condensaron dichas normas destinadas a crear un sistema de relaciones laborales moderno, garante del orden social capitalista ${ }^{15}$. El dictador combinó hábilmente represión con gestos de aparente "benevolencia" hacia los opositores del movimiento obrero. Algunos activistas prominentes pasaron detenidos o desterrados la mayor parte del tiempo durante su gobierno, pero de forma ocasional se les otorgó algunos meses de libertad bajo vigilancia policial, hasta se les dio la oportunidad de retirarse del todo de la política a condición de comprometerse a un "buen comportamiento" hacia las autoridades. A cambio de promesas similares, se permitió a diputados comunistas volver a ocupar sus escaños en el Parlamento. También se autorizó, bajo las mismas condiciones, el funcionamiento de algunas organizaciones en las que el PCCh había representado un papel prominente. El régimen alentó cuidadosamente la constitución de sindicatos legales. Aunque la legislación laboral había sido diseñada para debilitar en el aspecto político al movimiento sindical, sirvió para que los militantes del PCCh y de la Federación Obrera de Chile (FOCH) continuaran realizando - de manera limitada y cautelosa- actividades sindicales. Además, estimuló la creación de nuevas agrupaciones políticas diseñadas con el objetivo de canalizar el apoyo electoral de la clase obrera a su régimen. Ese fue el caso de la efímera Vanguardia Nacional de Obreros y Empleados (VNOE), formada en abril de 1927 por un grupo de excomunistas dispuestos a colaborar en la "reconstrucción nacional y la purificación administrativa" emprendida por el gobierno, también el de la Confederación Republicana de Acción Cívica (CRAC), colectividad que a partir de 1930 logró agrupar una gran cantidad de organizaciones de trabajadores, incluyendo el Congreso Social Obrero (CSO), que reunía mutuales, la Unión de Empleados de Chile (UECH) y numerosos sindicatos legales ${ }^{16}$.

La dictadura propinó golpes durísimos al PCCh cuya estructura -aún esencialmente asamblearia- no estaba en condiciones de resistir una prueba de este tipo: sucesivos comités centrales fueron apresados, numerosos cuadros fueron detenidos, torturados y relegados en islas del océano Pacífico o en el extremo sur del país, algunos de sus dirigentes se vieron obligados a partir al exilio y la mayoría de sus bases quedó a la deriva. El partido se redujo a unas cuantas decenas de militantes activos en distintas provincias cuyos vínculos con la estructura central se relajaron, incluso, en ciertos momentos, desaparecieron por completo.

A la defección de la mayoría de sus parlamentarios, quienes se sumaron al proyecto ibañista, pronto se añadieron nuevas tensiones producto de las diferentes posiciones que

${ }^{15}$ Sobre la política de Carlos Ibáñez en dirección del movimiento obrero, véase Jorge Rojas Flores, $\mathrm{La}$ dictadura de Ibáñez y los sindicatos (1927-1931), Santiago, Ediciones de la Dirección de Bibliotecas, Archivos y Museos, Centro de Investigaciones Diego Barros Arana, colección Sociedad y Cultura, 1993, vol. vI.

${ }^{16}$ Andrew Barnard, The Chilean Communist Party, 1922-1947, thesis present for the degree of Doctor of Philosophy in the University of London, London, University College, University of London, december 1977, pp. 115-119. Véase también Rojas, op. cit., passim. 
surgieron en su seno respecto de la táctica a desarrollar para enfrentar la dictadura. Así, por ejemplo, Bernardino Donoso, miembro del primer Comité Central que funcionó bajo la dictadura desde mayo de 1927 hasta agosto de 1928, se oponía a las "conspiraciones burguesas" contra el régimen y postulaba la no realización de alianzas de ningún tipo con los partidos burgueses opositores, mientras otros militantes eran proclives a establecer ciertas alianzas, al menos con la pequeña burguesía. Más tarde, en el seno de un nuevo Comité Central, se manifestaron fuertes diferencias respecto del tipo de organización a construir bajo la dictadura: mientras Isaías Iriarte sostenía que era necesario reorganizar y consolidar el aparato sobre la base de militantes abnegados antes de lanzarlos a la dirección de amplias masas, Rufino Rosas alegaba que era necesario abrir las puertas del partido a todos los que quisieran ingresar y también constituir una organización legal ${ }^{17}$. En los primeros días de enero de 1928, el mismo Rufino Rosas, durante su estadía en Moscú, solicitó consejo al Komintern para responder la disyuntiva estratégica que más tarde sería una de las principales causas de división de su partido: “¿Debemos aliarnos a la pequeña burguesía para derribar a Carlos Ibáñez o debemos luchar solos por la instauración del gobierno obrero-campesino?"18. La duda de Rufino Rosas no era compartida por dirigentes como Bernardino Donoso, quien se mostraba intransigente en su rechazo a toda colaboración, así fuese ocasional, con fuerzas burguesas, tal como lo expresó en una reunión del SSA celebrada en Buenos Aires el 19 de julio de $1928^{19}$.

La llegada a Chile, en febrero de 1929, del ítalo-argentino Victorio Codovilla, encargado del SSA, cambió la dinámica de las luchas al interior del partido chileno. Junto con los emisarios que luego enviaría desde Buenos Aires el SSA (Buró Sudamericano a partir de fines de 1931) intervinieron brutalmente en las pugnas internas de la organización "hermana". Estos misi dominici komintereanos lo hicieron valiéndose de la autoridad moral y política que les confería su papel de representantes del centro revolucionario mundial, y con recursos financieros que el debilitado partido trasandino estaba imposibilitado de conseguir por sus propios medios. Primero polemizaron con quienes sostenían posiciones discrepantes a las del SSA/BSA, luego realizaron trabajo fraccional contactando directamente a militantes y organizaciones de base, sin autorización de los organismos dirigentes del partido chileno, elaboraron y distribuyeron documentos, repartieron recursos para apoyar a quienes se sometían a sus indicaciones, cooptaron a militantes "seguros" para cargos de dirección, desprestigiaron a sus opositores e, incluso, montaron en Valparaíso un comité central paralelo al que funcionaba en Santiago, a fin de sustraer a sus miembros de la influencia que sobre ellos podía ejercer el senador

\footnotetext{
${ }^{17}$ La lucha fraccional al interior del PC chileno entre 1927 y 1933 ha sido tratada por varios autores. Véanse, entre otros, Olga Ulianova, "El Partido Comunista chileno durante la dictadura de Carlos Ibáñez (1927-1931): primera clandestinidad y ‘bolchevización' estaliniana”, en Boletín de la Academia Chilena de la Historia, $\mathrm{N}^{\circ} 111$, Santiago, 2002, pp. 385-436; Mariano Vega Jara, “Hidalguismo versus laferttismo? Crisis y disputa por la representación del comunismo en Chile, 1929-1933”, en Ulianova, Loyola y Álvarez (editores), op. cit., pp. 97-169; Gabriel Muñoz Carrillo, "Disputa por el comunismo en Chile. Estalinistas y oposicionistas en el partido de Recabarren (1924-1934)", informe de seminario de grado para optar al grado de licenciado en Historia, Santiago, Universidad de Chile, 2014.

18 "Informe sobre la situación del PC chileno elaborado en Moscú por Rufino Rosas, delegado del PCCH, 10.01.1928”, RTsJIDNI, 495.106.14, en Ulianova y Riquelme (editores), op. cit., tomo 1, pp. 311-316.

${ }^{19}$ Ulianova, "El Partido Comunista...", op. cit., pp. 407-411.
} 
Hidalgo, líder veterano cuya trayectoria en las filas de la organización databa desde la fundación (1912) de su antecesor directo, el Partido Obrero Socialista (POS) ${ }^{20}$.

La negativa de Manuel Hidalgo a aceptar la subordinación vertical al SSA y la reticencia de su grupo constituido en Comité Central Provisorio (CCP) en 1929 luego de la detención de un anterior Comité Central (CC) a asumir las orientaciones del "tercer período" adoptadas por la conferencia de partidos comunistas latinoamericanos realizada en Buenos Aires a comienzos de junio de 1929, exacerbó las contradicciones con el organismo komintereano asentado en Buenos Aires y en el seno del PCCh, provocando poco tiempo después una división que sería definitiva. A fines de 1929 llegó a Chile otro delegado del SSA con la misión de anular al CCP y combatir su proyecto de creación de un partido legal como instrumento táctico en la lucha contra la dictadura. Pocos meses más tarde, en agosto de 1930, cuando la mayoría de los miembros del CCP "hidalguista" se encontraba sufriendo penas de relegación, se constituyó en Valparaíso el CC bajo la dirección del SSA. Los puentes entre ambas fracciones estaban definitivamente cortados. Dos partidos comunistas -ambos denominados con el mismo nombre: Partido Comunista de Chile (sección chilena de la Internacional Comunista)- se disputarían la militancia y la legitimidad del comunismo. No obstante, hasta comienzos de 1933, los hidalguistas, cada vez más identificados con las ideas de la oposición de izquierda que en el ámbito internacional se venían articulando en el seno del movimiento comunista en resistencia al poder de Stalin en la Unión Soviética y en la Internacional, seguirían proponiendo la realización de un congreso de reunificación a la fracción leal al SSA/BSA, que encabezaban Elías Lafertte, Galo González, Carlos Contreras Labarca y Paulino González Alberdi, español nacionalizado argentino que actuaba como enviado del BSA en "su partido" chileno ${ }^{21}$.

Según la apreciación de Andrew Barnard, las políticas del "tercer período" chocaron contra de los esfuerzos de Hidalgo para organizar un frente unido con los opositores burgueses a Carlos Ibáñez. El rechazo de Hidalgo a aceptar las nuevas políticas y las órdenes del SSA, entre ellas abandonar su puesto en el Senado para consagrarse a la lucha frontal contra la dictadura y trabajar por la destrucción de los sindicatos legales, más que el reformismo y el colaboracionismo del que fue acusado, habría sido la causa de su expulsión por la facción rival. Su intransigencia, poco después que el PCCh hubiese sido aceptado como miembro de pleno derecho de la Internacional Comunista, durante un periodo en que este organismo intentaba acabar con Trotsky y pretendía imponer un grado mayor de uniformidad sobre sus miembros latinoamericanos, no podía quedar impune. Expulsado Hidalgo, el SSA generó un liderazgo dentro del PCCh que le debía por completo su posición y que, por lo mismo, sería totalmente manejable. Al impulsar la exclusión del senador, el SSA repetía en el PCCh la experiencia de la Internacional Comunista por medio de la purga de una figura de un estatus semejante al de Trotsky, proporcionando a sus dirigentes un chivo expiatorio a quien inculpar por sus errores y fracasos pasados ${ }^{22}$.

\footnotetext{
${ }^{20}$ Ulianova, "El Partido Comunista...”, op. cit., pp. 419-434; Vega, op. cit.; Muñoz, op. cit.

${ }^{21}$ Ibid. Sobre la vida y las actividades de Paulino González Alberdi en Chile, véase, Olga Ulianova, "Develando un mito: emisarios de la Internacional Comunista en Chile", en Historia, N41, vol. I, Santiago, enero-junio de 2008, pp. 118-121.

${ }^{22}$ Barnard, op. cit., pp. 128-129.
} 
Sin dejar de considerar la negativa de Hidalgo y su grupo a subordinarse de manera incondicional a la verticalidad del mando que pretendía imponer en "su partido" chileno el SSA, además del choque de personalidades y de estilos de trabajo -autoritario y verticalista del organismo komintereano, frente a una tendencia más proclive al diálogo, la negociación y el arreglo consensuado de los hidalguistas, al modo de la tradición recabarreana- es innegable que la división del PCCh a comienzos de la década de 1930 puede explicarse, en lo fundamental, por los efectos de las políticas sectarias derivadas de los análisis del "tercer período". Ello se ve confirmado por numerosas fuentes comunistas, incluso por voz del propio Victorio Codovilla, quien el 9 de agosto de 1929 en una reunión del SSA con "socio", delegado del $\mathrm{PCCh}^{23}$, al referirse a Hidalgo, luego de calificarlo como "confusionista", señaló que su política tendía a "luchar contra el gobierno nacional-fascista de Carlos Ibáñez, no por un gobierno obrero y campesino, sino que apoyado en la pequeña burguesía y ciertas capas de la burguesía descontentas del régimen actual, para establecer un régimen democrático liberal" ${ }^{24}$. Nuestra percepción es coincidente con la de Olga Ulianova, quien sostiene que las diferencias ideológicas de Hidalgo con el SSA se basaban en su oposición, "más intuitiva, aunque fundamentada teóricamente", a las posiciones sectarias de la política de "clase contra clase", agregando que "a diferencia de situaciones anteriores de divergencias de opiniones en el seno del PCCh, esta vez el conflicto desembocó en una primera oleada de purgas y defenestraciones doctrinarias, debido a la intervención del órgano sudamericano de la Komintern"25.

A continuación analizaremos como se manifestó la oposición entre ambas líneas -la de los adeptos de la autonomía partidaria y alianzas relativamente amplias, versus la de los seguidores incondicionales del SSA y de las políticas del "tercer período"- en el contexto de las primeras elecciones luego de la caída del dictador Carlos Ibáñez en el invierno de 1931.

\section{La caída de CARlos IbáÑez}

Y LA SALIDA A LA LUZ PÚBLICA DE DOS PARTIDOS COMUNISTAS RIVALES

La Gran Depresión que afectó al capitalismo mundial desde fines de 1930 dejó secuelas devastadoras en Chile, país más afectado del mundo por esta crisis, según un conocido informe de la Sociedad de las Naciones. Entre 1929 y 1932 las exportaciones de salitre (principal ingreso nacional) bajaron en un 91\%, provocando el colapso definitivo de esta actividad económica que ya no volvería a levantar cabeza. En 1932 las exportaciones agrícolas habían disminuido un 86\% respecto al periodo 1927-1929. Durante 1931 la producción industrial cayó un $25 \%$, la construcción -sector que tradicionalmente em-

\footnotetext{
${ }^{23}$ Identificado en otros documentos komintereanos como "Espinoza, obrero agrícola", Ulianova y Riquelme, op. cit., tomo 1, p. 401.

24 “Acta 42. Reunión con el delegado de Chile, agosto 9 de 1929”, RTsJIDNI, 495.106.22, en Ulianova y Riquelme (editores), op. cit., tomo 1, pp, 401-409. La cita textual en p. 403.

${ }^{25}$ Olga Ulianova, "El PC chileno durante la dictadura de Ibáñez (1927-1931): primera clandestinidad y ‘bolchevización' estaliniana”, en Ulianova y Riquelme (editores), op. cit., tomo 1, p. 256.
} 
plea gran cantidad de mano de obra- se vio restringida a la quinta parte en relación con el año anterior, el PGB bajó un 17,1\% y los jornales se redujeron en un tercio respecto del mismo periodo. El precio del cobre -segundo producto de exportación- pasó de 17,47 centavos la libra en 1929 a 5,06 en 1932. Hacia 1932-1933 el volumen total de las exportaciones chilenas había caído en un 64\% en relación con 1928-1929. El marasmo de la actividad productiva se vio acompañado por la disminución de créditos internacionales, circunstancia que redundó en un fuerte déficit fiscal, a pesar de las medidas de austeridad adoptadas por el régimen entre las que se incluyeron drásticas rebajas en los sueldos de los empleados fiscales. El descenso generalizado de precios, produjo en 1930-1931 una fase deflacionaria y las importaciones se vieron mermadas fuertemente, cayendo en un 88\% en 1932 respecto de 1929. El gobierno trató de hacer frente a la catástrofe económica subiendo los aranceles de ciertos productos a fin de desincentivar las importaciones y, por ende, el éxodo de divisas, imponiendo controles de cambio y declarando, el 15 de junio de 1931, una moratoria en el pago de la deuda externa ${ }^{26}$.

Las clases populares sufrieron con particular rudeza las consecuencias de la crisis: dos tercios de los trabajadores de la minería perdieron su empleo en 1930-1931, pasando de noventa y un mil a treinta y un mil. En 1932 solo quedaban ocho mil obreros en las explotaciones salitreras, en circunstancias de que tres años antes habían sido casi sesenta mil. La cesantía y el hambre fueron las principales consecuencias sociales de la crisis, miles de trabajadores desempleados y sus familias -en su mayoría provenientes de la región salitrera- se hacinaron en las calles o en improvisados albergues en Santiago y en otras grandes ciudades, recurriendo a las "ollas del pobre" para subsistir con mucha precariedad. El hambre, la desnutrición, la mendicidad, las enfermedades y epidemias proliferaron de manera alarmante ${ }^{27}$.

La crisis no tardó en manifestar sus efectos en el campo de la política. Algunas tibias medidas de apertura adoptadas por el dictador a mediados de 1931 -entre ellas el nombramiento del abogado radical Juan Esteban Montero, opositor moderado, como jefe de gabinete el 13 de julio- no impidieron que la crisis política estallara con violencia. En Santiago se realizaron multitudinarias manifestaciones contra el régimen encabezadas por los estudiantes universitarios, a las que luego se sumaron profesionales y algunos gremios de empleados, replicándose también en otras ciudades. Aunque Ibáñez seguía contando con el apoyo del Ejército y de la policía, su voluntad de combate estaba minada por una enfermedad y el sentimiento de abandono de una parte de su entorno, por lo que prefirió dejar el poder y partir al exilio el 26 de julio. Un gobierno provisorio encabezado por Juan E. Montero quedó encargado de asegurar la vuelta a la normalidad constitucional y emprender las medidas más urgentes de saneamiento económico.

${ }^{26}$ Simon Collier y William E. Sater, Historia de Chile 1808-1904, Cambridge, Cambridge University Press, 1996, pp. 197-198; Vial, op. cit., vol. Iv, pp. 443-481; Gabriel Salazar y Julio Pinto, Historia contemporánea de Chile, Santiago, LOM Ediciones, 2002, vol. III: La economía: mercados, empresarios y trabajadores, pp. 35-37; Armando de Ramón, Historia de Chile. Desde la invasión incaica hasta nuestros días (1500-2000), Santiago, Catalonia, 2003, p. 131.

${ }^{27}$ Un detallado estudio sobre la desocupación, el hambre, las ollas del pobre y los albergues en Juan Carlos Gómez Leyton, “Crisis, hambre y socialismo, 1931-1932”, en Andes, año v, N 7, Santiago, 1988, pp. 101-159. 
Prontamente se fijaron las elecciones presidenciales para el 2 de octubre, quedando poco después el ministro del Interior, Manuel Trucco, a la cabeza del Ejecutivo, ya que el sucesor "legal" de Carlos Ibáñez, Juan Esteban Montero, sería proclamado candidato por una amplia coalición "civilista" que incluía a los partidos Liberal, Conservador y Radical, además de numerosos profesionales que habían representado un papel destacado en la agitación política que había culminado en el derrocamiento de la dictadura. Frente a esta candidatura, a comienzos de septiembre, una "convención de las izquierdas" levantó la del expresidente Arturo Alessandri Palma, el "León de Tarapacá", en cuya administración (1920-1925) se habían iniciado las reformas destinadas a transformar el viejo Estado oligárquico en un moderno "Estado de compromiso" cargado de preocupaciones sociales. Sostenía esta postulación el "alessandrismo", una variopinta coalición de seguidores del exmandatario que incluía a disidentes del liberalismo y del radicalismo, además de la mayoría de los dirigentes y militantes del Partido Democrático $^{28}$. Juan Esteban Montero tenía más posibilidades de resultar vencedor, ya que, tal como sostienen Paul Drake y Verónica Valdivia, para los llamados "partidos históricos", resultaba más confiable que Alessandri puesto que no se asociaba a la anarquía, ni al comunismo, ni a los militares. Montero era reservado, un liberal a la usanza del siglo XIX, partidario fervoroso del laissez faire y de la legalidad. No constituía un peligro para ningún interés "respetable". Era, pues, el candidato ideal para la clase dirigente ${ }^{29}$.

Entretanto, las debilitadas huestes del comunismo criollo habían emergido de la clandestinidad divididas en dos grupos que buscaban con gran afán detentar el nombre de PCCh (sección chilena de la Internacional Comunista), capitalizando para sí la legitimidad de veinte años de historia propia, amén del prestigio de la Revolución Rusa y la Unión Soviética, hasta entonces unánimemente reivindicado por todas las corrientes del comunismo mundial. El sector encabezado por Elías Lafertte, Carlos Contreras Labarca, Galo González y Paulino González Alberdi ${ }^{30}$, se lanzó de inmediato a articular la FOCH. El 30 de julio, en una asamblea celebrada en el Hogar de los Tranviarios de Santiago, la Junta Ejecutiva Federal (JEF) de este organismo laboral presidida por Lafertte dio cuenta de sus actividades bajo la dictadura. El abogado Carlos Contreras Labarca, presentado como dirigente de la central sindical, sostuvo la urgencia de fortalecer la organización y de concentrar los esfuerzos del proletariado alrededor de ciertas

${ }^{28}$ Vial, op. cit., vol. v, pp. 28-32.

${ }^{29}$ Paul Drake, Socialismo y populismo. Chile 1936-1973, Valparaíso, Universidad Católica de Valparaíso, Instituto de Historia, 1992, p. 49; Verónica Valdivia Ortiz de Zárate, La milicia republicana. Los civiles en armas 1932-1936, Santiago, Ediciones de la Dirección de Bibliotecas, Archivos y Museos, Centro de Investigaciones Diego Barros Arana, colección Sociedad y Cultura, 1992, vol. II, p. 22.

${ }^{30}$ Pocos días antes de la caída del dictador, alrededor de quince militantes de la fracción pro SSA/BSA del PCCh fueron detenidos en Valparaíso al descubrir la policía una imprenta clandestina dirigida por José Díaz que funcionaba en el cerro Las Perdices. Junto a José Vega, fueron arrestados, entre otros, Paulino González Alberdi, José Manuel Contreras Tapia, el profesor primario Luis Morales Peña y Víctor Contreras Tapia. Según la prensa, la mayoría de los detenidos eran miembros del sindicato de tranviarios a la par que militantes comunistas. "15 detenidos en el asunto de la imprenta comunista", en El Mercurio, Santiago, 22 de julio de 1931. El último de los nombrados y Vega tendrían una destacada trayectoria en el PCCh, ocupando cargos en su dirección y en el Parlamento nacional. Véase también, "Carta de Paulino González Alberdi a la Comisión Sindical Latinoamericana en Montevideo. 05.08.1931”, RGASPI, 495.106.24, en Ulianova y Riquelme (editores), op. cit., tomo 2, pp. 57-59. 
reivindicaciones económicas inmediatas, la defensa de las libertades públicas, la lucha antiimperialista, la atención de los desocupados y la recuperación de los bienes (imprentas, locales, etc.) arrebatados por la dictadura a las organizaciones obreras. Se refirió, asimismo, a la necesidad de que el proletariado mantuviera inalterable una posición de clase frente a los acontecimientos del momento. Al finalizar el acto, se leyeron las resoluciones previamente aprobadas por la JEF en las que este órgano colegial declaró su intención de asumir la dirección de la Federación hasta la realización de una próxima convención nacional, Carlos Contreras Labarca llamó a impulsar una campaña por la liberación de los presos políticos e hizo "un fervoroso llamado a los obreros, empleados y campesinos de Chile para la formación del Frente Único Obrero, como un arma para luchar por la emancipación de los trabajadores" ${ }^{\prime 31}$.

\section{LAS CANDIDATURAS PRESIDENCIALES RIVALES DEL COMUNISMO CHILENO \\ (AGOSTO, FASE INICIAL)}

En forma paralela a estos hechos, este sector del PCCh colocado bajo el liderazgo primordial del comisionado del BSA, trabajó con celeridad por montar una candidatura presidencial para difundir sus posiciones y asegurarse la representación del comunismo. El 5 de agosto, recién liberado por orden de un juez, Paulino González Alberdi escribió una carta a la Comisión Sindical Latinoamericana dependiente de la Internacional Sindical Roja (Profintern), informando en detalle de los acontecimientos acaecidos en Chile ${ }^{32}$. Junto con asegurar que los viejos líderes comunistas chilenos que volvían del exilio y Carlos Contreras Labarca, a pesar de estar "con el partido", no daban aún garantías, el delegado del BSA fijó siete tareas urgentes, siendo la primera de ellas la proclamación de un candidato presidencial que, a su juicio, debía ser Elías Lafertte ${ }^{33}$. El 9 de agosto, el Comité Central de su fracción adoptó la decisión propuesta por González Alberdi ${ }^{34}$, así tres días más tarde este informó desde Santiago al BSA, que antes de concretarse las postulaciones de Montero y Alessandri, "la candidatura Lafertte que nos hemos apresurado a lanzar", congregaría "grandes masas obreras, campesinas, pequeño burguesas", lo que obligaría -a su juicio- "a distintos bandos burgueses a tender también por este motivo hacia el frente único", al cual ya marchaban por temor a las masas ${ }^{35}$. Además de solicitar recursos económicos para llevar adelante este acuerdo ("La campaña presidencial y especialmente el Congreso de la FOCH requieren dinero" ${ }^{36}$ ), el delegado de la Komintern puso el acento en esta carta en desacreditar la política de "frente único civil" propiciado -según su in-

31 "La Federación Obrera de Chile reasume públicamente sus funciones", en El Diario Ilustrado, Santiago, 30 de julio de 1931 .

${ }^{32}$ Este organismo, al igual que el BSA, se había radicado en Montevideo luego del golpe de Estado ocurrido en Argentina en septiembre de 1930.

33 "Carta de Paulino González Alberdi a la Comisión Sindical Latinoamericana en Montevideo. 05.08.1931”, RGASPI, 495.106.25, en Ulianova y Riquelme (editores), op. cit., tomo 2, pp. 60-61.

34 “Comunistas proclamaron candidato a presidente", en El Diario Ilustrado, Santiago, 10 de agosto de 1931.

35 "Informe de Paulino González Alberdi, emisario de KOMINTERN desde Santiago de Chile al Buró Sudamericano. 12.08.1931”, RGASPI, 495.106.25, en Ulianova y Riquelme (editores), op. cit., tomo 2, pp. 63-64.

${ }^{36}$ Op. cit., p. 65. 
forme- por otros grupos, incluyendo varios colectivos socialistas de reciente formación, por Hidalgo y Sepúlveda Leal (otro expulsado del PCCh), sin que ello fuera obstáculo para proponer, como lo venía y continuaría haciéndolo, la constitución de un "frene único proletario" de acuerdo con la línea del "tercer período". "En consecuencia-sostenía este encargado- el fuego lo desencadenaremos contra el gobierno y el frente único civil, facilitadores con su política de nuevos golpes militares, organizadores del fascismo civil y sostendremos la consigna y el desarme de carabineros, armamento del proletariado y fuerte acción de masas por sus reivindicaciones políticas y económicas"37.

Olga Ulianova observa al respecto que la expresión "fascismo civil" para referirse a un amplio campo de opositores a Carlos Ibáñez, en su mayoría de clase media, parecía ser el equivalente al concepto de "socialfascismo" atribuido por los partidos comunistas europeos a la socialdemocracia ${ }^{38}$. Coincidiendo con esta interpretación, agregamos que dicha manifestación de la línea ultrasectaria komintereana de aquellos años en Chile, necesariamente debía sufrir una adaptación como la formulada por González Alberdi. Puesto que aún no existía un partido socialista (este se formaría recién en 1933) y el Partido Democrático no reunía todas las características de una organización socialdemócrata, el "socialfascismo" debía encarnarse en otros sujetos políticos, a decir, embrionarios grupos socialistas, hidalguistas y aquellos grupos que pretendieran conquistar la misma base social que el comunismo oficialista en vías de "bolchevización" aspiraba representar de manera monopólica.

El "frente único civil", para asegurar la salida de los militares de la actividad política y volver a la normalidad constitucional que propiciaban quienes habían formado la oposición burguesa a Carlos Ibáñez más algunos sectores de izquierda, fue criticado con dureza por el PCCh oficial. Desde las páginas de Bandera Roja, flamante "órgano central" de este partido, se denunciaron los llamados del "civilismo" como una maniobra destinada a "inducir a las masas laboriosas al abandono de la lucha contra el imperialismo y sus instrumentos, al abandono de sus reivindicaciones económicas, a la formación de un solo block con los terratenientes, los banqueros, los industriales"39. Según esta perspectiva, el proletariado no podía comprometerse en una política de "unión sagrada" con sus enemigos y el combate contra el militarismo debía realizarse desde la independencia de clase, ya que solo desde sus filas se podía desarrollar una verdadera acción antimilitarista. Presagiando la incapacidad de los partidarios del "frente único civil" para converger en una candidatura unitaria puesto que, solo con los análisis komintereanos para Chile, las pugnas entre los partidarios del imperialismo yanqui (seguidores de Juan Esteban Montero) y los del imperialismo británico (alineados con Arturo Alessandri Palma) harían fracasar dicho proyecto, la fracción comunista leal al BSA explicó la postulación de Elías Lafertte a la Presidencia de la República como "un episodio de la lucha de los explotados contra los explotadores". Las acciones decisivas, declaró su Comité Central, serían las huelgas obreras contra el hambre, los movimientos campesinos contra "la ex-

\footnotetext{
37 "Informe de Paulino González Alberdi, emisario de KOMINTERN desde Santiago de Chile al Buró Sudamericano. 12.08.1931"..., op. cit., p. 64.

${ }^{38} \mathrm{Ibid}$.

39 “Por nuestra política independiente" [Editorial], en Bandera Roja, № 1, Santiago, 13 de agosto de 1931.
} 
plotación feudal" y la movilización antiimperialista de obreros, campesinos, empleados, estudiantes e intelectuales revolucionarios. Acompañando esta candidatura, la dirección del PCCh oficial lanzó un llamado a la acción para conseguir reivindicaciones como jornada de siete horas, alza de salarios, pago de subsidios a los cesantes, no pago de alquileres, "derogación del Código Fascista del Trabajo", disolución inmediata del cuerpo de Carabineros, creación de guardias obreras armadas en los lugares de trabajo, no pago de los arrendamientos agrícolas, expropiación sin indemnización de los grandes terratenientes y entrega de la tierra a quienes la trabajaban, "castigo enérgico a Ibáñez y de todos los que usufructuaron con la dictadura" (incluyendo la incautación de sus haberes), expropiación de los bienes de la Iglesia, liberación inmediata de los obreros apresados por un supuesto atentado a Ibáñez, desconocimiento de la deuda con los imperialistas, nacionalización de minas, salitreras y empresas que estaban en sus manos, "entrega de la tierra robada a los indios" y derecho de ellos a "constituir sus propios estados", amplios derechos de reunión, prensa, organización y huelga, además del mejoramiento de las condiciones de vida y trato para los soldados y marineros. Las consignas a favor del gobierno obrero y campesino, contra el imperialismo y "contra el fascismo representado por el frente único civil y todo golpe militar", cerraban este programa inspirado en la concepción de la revolución democrático-burguesa de contenido antioligárquico, antifeudal y antiimperialista que la Komintern había definido para países que, como Chile, eran incluidos en la categoría de semicoloniales ${ }^{40}$.

La candidatura de Manuel Hidalgo proclamada pocos días antes por el PCCh de oposición ${ }^{41}$ tuvo algunos rasgos programáticos y discursivos bastante coincidentes con los de la fracción laferttista. Desde las páginas de su flamante órgano, La Chispa, este grupo denunció al "frente civil" como una institución de clase de la burguesía para combatir al proletariado y llamó a oponerle el "frente único de los explotados" o "agrupación de las fuerzas obreras, campesinas, de soldados, de marineros, de empleados y de profesores primarios en sus propias organizaciones de clase dirigidas por el Partido Comunista, organización revolucionaria del proletariado mundial" ${ }^{42}$. Su programa presidencial presentado a fines de agosto en un meeting realizado en un teatro santiaguino, incluía entre otros puntos: no pago de la deuda externa; expropiación de los latifundios; control estatal del comercio exterior; socialización de las tierras, de los medios de producción y de cambio; subsidio a los desocupados a costa del Estado y los capitalistas; reducción de la jornada laboral a siete horas; suspensión total del trabajo nocturno y de las horas

40 "Por nuestra política independiente" [Editorial]..., op. cit. Días más tarde, la dirección de esta fracción publicaría un programa muy similar al señalado, incluyendo algunos elementos nuevos como precisiones respecto de los salarios de hombres, mujeres y jóvenes, también acerca de salarios mínimos por regiones, entre otros. "El Partido Comunista de Chile (sección chilena de la I.C.) frente a la elección presidencial. Programa de reivindicaciones inmediatas", en Bandera Roja, № 3, Santiago, 27 de agosto de 1931. También fue publicado, entre otros periódicos, en El Comunista, N $^{\circ}$ 2, Antofagasta, 2 de octubre de 1931.

41 "El Partido Comunista lanza la candidatura presidencial del senador Hidalgo", en El Diario Ilustrado, Santiago, 13 de agosto de 1931; "La candidatura presidencial del senador comunista, señor M. Hidalgo", en El Mercurio, Santiago, 13 de agosto de 1931; "Candidatura presidencial del Senador Comunista, compañero Manuel Hidalgo", en La Chispa, № 1, Santiago, 20 de agosto de 1931.

42 "Contra el frente civil", en La Chispa, $\mathrm{N}^{\circ}$ 1, Santiago, 20 de agosto de 1931; "A la conquista del poder", en La Chispa, № 2, Santiago, agosto de 1931. 
extras; semana de treinta y ocho horas de trabajo sin reducción de sueldo; explotación colectiva de la tierra y de la gran propiedad agrícola por cuenta del Estado; término de las obras públicas, edificios, tranques y caminos a cargo de los consejos industriales de los obreros; implantación de una legislación social de acuerdo con las verdaderas necesidades de los obreros, empleados, campesinos y profesionales; igualdad de salario para ambos sexos; fijación de un canon de arrendamiento máximo y suspensión de los pagos de las rentas de arriendo durante la crisis; construcción de viviendas higiénicas por el Estado para los trabajadores y administración de las mismas por las organizaciones obreras; nacionalización del crédito y creación de un banco del Estado; abolición de los monopolios; devolución de las tierras y bienes usurpados a los indígenas; educación gratuita en todos los niveles, dejando la enseñanza primaria como facultad privativa del Estado; igualdad de los derechos políticos y sociales para ambos sexos; disolución de la Compañía de Salitres de Chile, COSACH (empresa mixta conformada por el Estado y capitalistas privados); devolución de los dineros fiscales usurpados durante la dictadura y castigo a los culpables; reconocimiento diplomático de la Unión Soviética; etcétera ${ }^{43}$.

No obstante la gran cercanía programática de ambas candidaturas comunistas, en su gestación y desarrollo, la postulación de Manuel Hidalgo intentó aparecer como una iniciativa amplia que sobrepasaba el área tradicional de influencia del partido, constituyéndose como el representante de todas "las izquierdas". Para lograrlo, desde mediados de agosto se realizaron numerosas reuniones que incluyeron a "hidalguistas", diversos grupos socialistas, laboristas, demócratas y un sinnúmero de personas y organizaciones sociales caracterizadas por su común oposición al ibañismo y al "civilismo" nucleado principalmente en torno a la figura de Juan Esteban Montero. Además del apoyo de su propio partido, Hidalgo sumó el de pequeñas colectividades como la Unión Cívica de los Laboristas de Chile (animada por algunos sindicalistas, exmilitantes comunistas y exfochistas), el Partido Socialista Marxista ${ }^{44}$, el Partido Socialista de Orden, un Comité Universitario ad hoc y alrededor de treinta y siete organizaciones sociales, pero no consiguió retener a socios potenciales como la Legión Republicana de Pedro León Ugalde, el Partido Democrático y un fantasmal "Partido Socialista de Chile"45, quienes no tardaron en denunciar la pretensión de los hidalguistas de imponer a toda costa su candidato,

43 "Partido Comunista de Chile. Candidatura Presidencial del Senador Comunista Compañero Manuel Hidalgo", en La Chispa, № 2, Santiago, agosto de 1931; "De genuino comunista fue calificado el señor Hidalgo", en El Diario Ilustrado, Santiago, 30 de agosto de 1931.

${ }^{44}$ No existen estudios específicos sobre esta ni las otras pequeñas organizaciones socialistas que acompañaron a Manuel Hidalgo en su candidatura en 1931. En general, la historiografía se limita a mencionarlas, entregando algunos escasos datos sobre sus líderes y propuestas, en tanto elementos que participaron en la República Socialista de junio de 1932 y en la fundación del Partido Socialista de Chile en abril de 1933. Véase, entre otros, Luis Cruz Salas, Los partidos populares: 1931-1941, memoria para optar al título de profesor de Estado con especialidad en Historia y Geografía Económicas, Santiago, Universidad Técnica del Estado, 1969, pp. 64-70; Julio César Jobet, El Partido Socialista de Chile, Santiago, Ediciones Prensa Latinoamericana, 1971, tomo 1, pp. 65-67; Paul Drake, Socialismo y populismo. Chile 1936-1973, Valparaíso, Universidad Católica de Valparaíso, Instituto de Historia, 1992, pp. 120-122; Luis Cruz Salas, La República Socialista del 4 de junio de 1932, Santiago, Ediciones Tierra Mía, 2002, pp. 14-15.

${ }^{45}$ Esta minúscula organización, de existencia solo nominal, no figura entre los referentes que en 1933 convergieron para fundar efectivamente el Partido Socialista de Chile. Los nombres de sus representantes tampoco aparecen en la lista de fundadores. Jobet, op. cit., tomo 1, pp. 65-66, 77-78. 
rompieron con la emergente coalición y se unieron a una "convención de izquierdas" que proclamó la candidatura del expresidente Alessandri ${ }^{46}$.

Las campañas de ambas fracciones comunistas estuvieron plagadas de ataques y mutuas acusaciones de traición a la causa del proletariado y del comunismo. El sector laferttista u oficialista puso tanto o más énfasis en combatir la candidatura de Hidalgo que las de Montero y Alessandri, como puede observarse en documentos públicos y en las comunicaciones entre el emisario Paulino González Alberdi, el CC del PCCh, el BSA y el Lender-Secretariado Latinoamericano en Moscú de la Komintern. Según el encargado komintereano responsable de dirigir in situ al partido chileno, era evidente que Hidalgo se presentaba como candidato "a cuenta del frente único civil y de los propiciadores de la candidatura única burguesa para restar votos a Lafertte", de lo que deducía la necesidad de desenmascararlo y de anunciar de inmediato la postulación de este último ${ }^{47}$. Consecuentemente con esta mirada, tres días más tarde, el CC del PCCh publicó un llamamiento a los obreros y campesinos en el que se vertían conceptos muy similares, sin duda inspirados (o tal vez redactados) por su asesor komintereano. En uno de sus pasajes, la dirección laferttista afirmaba con acritud:

"La Cosach, este pulpo imperialista dirigido desde yanquilandia, reduce la producción para que los precios no bajen y hace que cada obrero produzca más, ganando menos, condenado a morir de hambre al proletariado pampino. En las minas de cobre, mientras aumentaba sensiblemente la cantidad y la calidad del mineral producido, el personal baja de 22 mil a 16 mil hombres, según estadísticas oficiales. El personal ferroviario sufre rebaja de sueldos, despidos y prolongación de la jornada de trabajo. Las fábricas solo trabajan media semana. Los campesinos no pueden pagar los arrendamientos porque no encuentran a quién vender su producción. ¿Qué hacen Montero, Alessandri y los traidores como Manuel Hidalgo o Sepúlveda Leal frente a esta situación?

¡Ellos, como buenos agentes del imperialismo, aconsejan el frente único civil y el candidato presidencial único, para desviar a los obreros y campesinos de la lucha por sus reivindi-

46 "Don Manuel Hidalgo es el candidato de las izquierdas", en El Mercurio, Santiago, 18 de agosto de 1931; "Se propicia una convención de fuerzas de izquierda para proclamar una candidatura presidencial única", en El Mercurio, Santiago, 19 de agosto de 1931; "Secretaría general de la candidatura de Manuel Hidalgo", en El Diario Ilustrado, Santiago, 20 de agosto de 1931; "La designación del candidato único de los partidos de izquierda", en El Mercurio, Santiago, 21 de agosto de 1931; "Mañana se efectuará la reunión de los dirigentes de izquierda para estudiar la cuestión presidencial", en El Mercurio, Santiago, 22 de agosto de 1931; "La candidatura de izquierda de don Manuel Hidalgo", en El Diario Ilustrado, Santiago, 22 de agosto de 1931; "Candidatura presidencial de izquierda" y "La candidatura presidencial de las izquierdas", en El Diario Ilustrado, Santiago, 23 de agosto de 1931; "Hoy se efectuará la reunión de representantes de izquierda", en El Mercurio, Santiago, 23 de agosto de 1931; "Sin resultados positivos la Convención Nacional izquierdista" y "La asamblea celebrada ayer por algunos partidos obreros izquierdistas", en El Diario Ilustrado, Santiago, 24 de agosto de 1931; "Don Manuel Hidalgo fue proclamado candidato único de las izquierdas a la presidencia de la República", en El Mercurio, Santiago, 24 de agosto de 1931; "Las fuerzas de izquierda eligieron como candidato a la presidencia al camarada Manuel Hidalgo", en La Chispa, №2, Santiago, agosto de 1931; "Las fuerzas izquierdistas celebrarán una convención”, en El Diario Ilustrado, Santiago, 26 de agosto de 1931; "El Partido Demócrata se dirige a sus correligionarios del país", en El Diario Ilustrado, Santiago, 31 de agosto de 1931. Sobre la proclamación de la candidatura de Alessandri y su campaña, véase Vial, op. cit., vol. v, pp. 30-34.

47 "Informe de Paulino González Alberdi, emisario de KOMINTERN desde Santiago al BSA. 13.08.1931”, RGASPI, 495.106.25, en Ulianova y Riquelme (editores), op. cit., tomo 2, p. 69. 
caciones. Siguiendo igual política que Ibáñez, ellos quieren que en nombre de lo difícil de la situación, de la civilidad y de la constitución, los trabajadores se resignen a morir de hambre, y acepten que los imperialistas, los terratenientes y la burguesía nacional, se descarguen de la crisis explotándoles aún más!

Y cuando el Partido Comunista proclama a Lafertte como candidato proletario, toda esa gente apoya a Hidalgo, falso comunista, para sembrar la confusión y tratar de romper el frente proletario, beneficiando al frente único burgués. Hidalgo, que bajo la dictadura luchó por liquidar el Partido Comunista y formar un Partido Comunista legalizado por Ibáñez para servir al fascismo y apagar la llama comunista, y hace ahora de provocador, utilizando un lenguaje demagógico" 48 .

A fines de agosto, el BSA afincado en Montevideo reforzó la interpretación de su comisionado al sostener en carta enviada al CC de "su partido" chileno que "el traidor y lacayo de la burguesía nacional", Manuel Hidalgo, estaba tratando de "transformarse en la figura central que reúna en su entorno a todos los elementos contrarrevolucionarios de la burguesía y pequeña burguesía en su lucha contra el Partido Comunista, contra la lucha de los obreros y campesinos por sus reivindicaciones inmediatas económicas y políticas", concluyendo:

"Desde este punto de vista, Hidalgo representa el mayor peligro para la orientación revolucionaria del proletariado de Chile. Demócratas ibañizantes, anarquistas, estudiantes socialistas, todos juntos declaran la guerra al partido del proletariado, agrupándose alrededor del renegado del comunismo, del senador Hidalgo"49.

Pocos días después, el BSA remachó en una nueva carta a la dirección de "su partido" chileno la definición sobre el peligro principal en el seno del movimiento obrero, ampliándola a otros referentes que constituían una desagradable competencia:

"El partido debe reconocer que en la actual etapa del desarrollo de las luchas revolucionarias de masas, las agrupaciones pequeño-burguesas y sus dirigentes (el renegado Hidalgo, el aventurero Pedro León Ugalde, los 'socialistas marxistas', etc.) constituyen el freno más serio y el peligro más grande para el desarrollo del movimiento revolucionario. La lucha de esos grupos que utilizan una fraseología revolucionaria, está dirigida únicamente hacia la salvación de los fundamentos del estado burgués. [...] Particularmente, la burguesía se sirve para desorientar y escisionar [sic] las masas, del traidor Hidalgo que intenta aparecer ahora como comunista después de haber sido expulsado del Partido por su posición vergonzosa del apoyo al gobierno de Ibáñez y de traición abierta a la causa del proletariado" ${ }^{50}$.

${ }^{48}$ El Partido Comunista a los obreros y campesinos, Santiago de Chile, 16 de agosto de 1931, folleto adjunto al oficio $\mathrm{N}^{\circ} 743$ de Tomás Allende Castro, gobernador de Melipilla al ministro del Interior, San Antonio, 25 de agosto de 1931, en Archivo Histórico Nacional, Fondo Intendencia de Santiago (en adelante AHN, FIS), vol. 790, Comunicaciones recibidas $\mathrm{N}^{\circ}$ 4001-4250, agosto a septiembre de 1931, doc. $\mathrm{N}^{\circ}$ 4008, fjs. 1-3.

49 "Carta del Buró Sudamericano de KOMINTERN al Partido Comunista de Chile. 27.08.1931", Montevideo, Agosto 27-1931, RGASPI, 495.106.25, en Ulianova y Riquelme (editores), op. cit., tomo 2, p. 74. Las cursivas son nuestras.

50 "Carta del Buró Sudamericano de KOMINTERN al Comité Central del PC chileno. 07.09.1931", Montevideo, Agosto 27-1931, RGASPI, 495.106.25, en Ulianova y Riquelme (editores), op. cit., tomo 2, p. 80. 
Los clichés estandarizados y el lenguaje komintereano estereotipado, exacerbado por las tesis del "tercer período" y de las políticas de "clase contra clase", son transmitidos con particular virulencia en esta misiva al partido chileno en proceso de "bolchevización": "El trotzkismo contrarrevolucionario, los jefes policiales del anarquismo, los demócratas ligados directamente con el imperialismo inglés, constituyen la base, el ambiente y la bandera del renegado Hidalgo" 51 . La acusación de "trostskismo" contra Manuel Hidalgo y sus camaradas comenzó a ser utilizada más profusamente durante la campaña electoral por el BSA y sus agentes en las comunicaciones con el partido chileno y con el Lender-Secretariado Latinoamericano en Moscú de la Komintern. Esto como una forma de cerrar filas en torno a la posición de este último organismo ya del todo controlado por los hombres de Iósif Stalin y obtener su apoyo para la línea de trabajo desarrollada por el BSA en Chile. El cargo de herejía ideológica era sostenido, de acuerdo con la práctica estalinista imperante en el movimiento comunista internacional de obediencia moscovita, sobre la base de informaciones deformadas o falsas. Aplicando estos procedimientos, el programa de gobierno de Hidalgo, que incluía tanto reivindicaciones económicas inmediatas como objetivos políticos más vastos, era presentado de la siguiente manera ante los encargados de América Latina de la Komintern asentados en Moscú:

\begin{abstract}
"Algunos compañeros que vivieron muchos años en el destierro también tenían sus dudas, pero nosotros las superamos sin pérdidas ni dificultades. La mayoría aplastante de los compañeros están en contra de esas medidas y la maniobra del enemigo fracasó. Está claro que aquello no significa que la candidatura de Hidalgo no causará confusión en las filas de los obreros. Hidalgo lleva a cabo sus luchas electorales bajo las consignas como 'con Lenin y Trotsky', 'en la URSS no hay cesantía', exige la disolución de la COSACH y una serie de otras reivindicaciones. Junto con esto lucha contra los comunistas y declara que ahora no es tiempo de lanzar las reivindicaciones económicas ya que en la orden del día está la revolución" ${ }^{\text {"52. }}$.
\end{abstract}

La candidatura de Elías Lafertte enfatizó la legitimidad que se desprendía de su íntima asociación con el BSA de la Komintern y explotó al máximo el prestigio que la FOCH aún mantenía en franjas de trabajadores, obteniendo algunos dividendos políticos electorales de su esfuerzo por volver a levantar la vieja y disminuida central sindical $^{53}$. Muchas personas seguían asociando de manera casi automática a la FOCH con el PCCh, por ende, quienes controlaran sus estructuras podían sacar ventaja en la disputa por la representación del comunismo en el país. Desde su privilegiada posición de secretario general de la $\mathrm{FOCH}$, Lafertte tenía la posibilidad de canalizar en favor de su campaña el poder de convocatoria de la organización sindical. De este modo fue aclamado en una gran manifestación de cesantes realizada en Santiago el 14 de agosto, cuando Contreras Labarca anunció que el PCCh lo había designado candidato a la Presidencia de la Repú-

51 “Carta del Buró Sudamericano de KOMINTERN al Comité Central del PC chileno. 07.09.1931”..., op. cit., p. 75 .

52 "Carta desde la sede del BSA al Lender-Secretariado Latinoamericano en Moscú. 04.09.1931”, Montevideo, 4 de septiembre 1931, RGASPI, 495.79.154, en Ulianova y Riquelme (editores), op. cit., tomo 2, p. 77.

53 "La demostración del hambre", en Justicia, Santiago, 15 de agosto de 1931. 
blica $^{54}$. Es por esto que los consejos fochistas que lograron reconstruirse durante el invierno de 1931, entregaron su apoyo a la candidatura presidencial del sector oficialista que empujaba su nueva articulación. Así, por ejemplo, cuando Roberto Pinto, secretario general de la campaña de Hidalgo, solicitó el apoyo del Consejo de Oficios Varios fochista de Cauquenes para su abanderado, este cuerpo le comunicó de manera cortés, pero inequívoca que un mes antes, en el momento de su reorganización, se había adoptado la decisión de sostener la postulación de Elías Lafertte ${ }^{55}$. Aunque la FOCH, reconstituida luego de la caída de la dictadura, intentó no aparecer en una simbiosis total con el PCCh, presentando sus periódicos no como órganos oficiales de ambas entidades (así había ocurrido hasta 1927), la militancia comunista de sus principales dirigentes y la coincidencia prácticamente total de sus demandas con las del partido, favorecía la campaña de Lafertte. La reestructuración de los consejos fochistas durante el invierno de 1931 marchó a la par con esta candidatura, los meetings de la central sindical siempre eran encabezados por líderes comunistas, quienes agitaban los temas, reivindicaciones y consignas comunes de ambas instituciones con provecho evidente para su abanderado ${ }^{56}$. No obstante la mayor atención puesta en aspectos formales a fin de no incurrir de nuevo en la confusión entre el partido y el sindicato, las necesidades de la campaña electoral y de la lucha contra los disidentes, hicieron aflorar los viejos reflejos, de modo tal que los dirigentes del partido obtuvieron que la convención fochista realizada a fines de septiembre expulsara de sus filas a Hidalgo "por haber traicionado la causa de los trabajadores" 57 , y recomendara a sus asociados votar por Elías Lafertte por ser la "única candidatura anticapitalista, antiimperialista" 58.

Los hidalguistas, como ya está dicho, sin ocultar su identidad comunista, proyectaron una imagen más amplia y unitaria, tratando que su líder apareciera como el representante de "las izquierdas", aunque, en contradicción con esta pretensión, el Comité Central de este partido declaró que se reservaba toda la dirección de la campaña, que las comisiones que se designaran trabajarían de acuerdo con sus directivas y, más tarde, ante rumores infundados sobre un posible retiro de su candidatura, sostuvo con igual fuerza que en tanto militante del PCCh, solo esta colectividad podía pronunciarse sobre la permanencia o el abandono de la postulación ${ }^{59}$. Con todo, Hidalgo logró articular un

54 "La demostración del hambre", en Justicia, Santiago, 15 de agosto de 1931.

${ }_{55}$ Archivo Histórico Nacional, Fondo Manuel Hidalgo (en adelante AHN, FMH), Carta de Pedro Yévenes, secretario general, Mercedes de Palavecino, secretaria de actas y Francisco Palavecino, del Consejo de Oficios Varios de Cauquenes a Roberto Pinto, Cauquenes, 21 de septiembre de 1931, sin catalogar. Este valioso fondo, hasta ahora no explotado por los historiadores, puede ser considerado un verdadero archivo confidencial del PCCh de la década de 1920 y comienzos de la siguiente. Contiene actas, circulares, informes y mensajes, la mayoría de carácter interno o confidencial, de las distintas organizaciones partidarias. Asimismo, se encuentran cartas entre las dirigencias del PCCh y algunos emisarios komintereanos, que no aparecen en la compilación elaborada por Olga Ulianova y Alfredo Riquelme. También conserva correspondencia no oficial entre militantes.

56 “Concentración en Rancagua", en Justicia, Santiago, 22 de agosto de 1931.

57 "Hidalgo es expulsado de la FOCH", en Bandera Roja, N4, Santiago, 1 de octubre de 1931.

58 "La Convención de la FOCH recomienda al proletariado la candidatura de Elías Lafertte", en Bandera Roja, $\mathrm{N}^{\circ} 4$, Santiago, 1 de octubre de 1931.

59 "La candidatura de Manuel Hidalgo unifica a todos los elementos obreros del país. Una enorme cantidad de adhesiones han llegado al candidato y al partido desde Valparaíso y demás provincias", en $L a$ Chispa, $\mathrm{N}^{\circ} 1$, Santiago, 20 de agosto de 1931. 
discurso más amplio y flexible que el de la ortodoxia comunista (oficialista o de oposición), acorde con el perfil de "candidato de las izquierdas". En las entrevistas de prensa, el senador comunista usó un lenguaje sencillo, no ortodoxo, incluyente, desprovisto de clichés, adecuado para la comprensión de un público no habituado a la jerga partidaria. Asimismo, se preocupó por ampliar las fronteras del frente único, no limitándolo exclusivamente a los asalariados, sino que incluyó, también, a los pequeños capitalistas. A mediados de agosto, al ser consultado por la revista Zig-Zag sobre si la parcelación de las tierras sería una solución para la angustiosa situación económica de muchas personas, declaró:

"No creo aceptable una solución que no traería ninguna ventaja a la economía nacional, porque es anticientífica y antieconómica.

Lo único que proporcionaría un bienestar al país, sería propender a las Cooperativas, como único medio de producción intensiva y económica. Necesitamos el cultivo científico en todas las ramas de la producción, para independizarnos económicamente del extranjero y ocupar el máximum de brazos.

Solo poniendo en práctica un programa de reconstrucción nacional con base económica que mire a la producción y no a la supresión desmesurada de servicios y empleados, podríamos considerarnos libres y gozar de libertad"60.

Poco después, respondió de la siguiente manera a la pregunta de un periodista del semanario Sucesos acerca de quienes lo acompañarían en el gobierno en el caso de triunfar:

"Los que pertenezcan a las clases asalariadas y los que simpaticen con la idea. No hay que olvidar que en las clases asalariadas están los hombres preparados: son los de la llamada clase media que hoy sufren la más angustiosa tragedia del hambre, explotados por el capital: su posición en el momento actual no puede ser otra que de las izquierdas. Los pequeños capitalistas y agricultores, los profesionales que sienten la amargura de un porvenir incierto por falta de actividad a sus conocimientos en esta crisis eterna que ha sumido el capitalismo al mundo. Este factor es el que produce en la actualidad el determinismo económico de la clase media explotada" ${ }^{91}$.

Consultado sobre los temores que infundía su partido en ciertas capas de la población debido a su posición sobre "la constitución de la familia a base de excesivas libertades", el "candidato de las izquierdas" expresó con tono tranquilizador:

"Los que hablan de socializar la familia y la mujer no saben que dicen dos monstruosidades.

En un Estado constituido de acuerdo con nuestros ideales, se soluciona el mayor de los obstáculos de la felicidad humana, cual es la situación económica, que impide a los padres alimentar, vestir y educar como es debido a sus hijos. [...]

La familia no sufre alteraciones del estado actual al socialista, sino en lo que se refiere a su mejoramiento económico, que influye en su condición moral. No concebimos la esclavitud de la mujer que vende sus sentimientos para contraer matrimonio por interés" ${ }^{\prime 2}$.

\footnotetext{
60 "Conversando con el Senador don Manuel Hidalgo", en Zig-Zag, N 1382, Santiago, 15 de agosto de 1931.

${ }_{61}$ "Con el candidato de las izquierdas", en Sucesos, Santiago, 3 de septiembre de 1931.

${ }^{62}$ Ibid.
} 
La apertura hacia sectores susceptibles de unirse al frente único en su versión hidalguista, no redujo la virulencia de esta bandería del comunismo chileno en la polémica con los laferttistas. Los líderes de la facción seguidora del BSA fueron acusados de actuar en función de "innobles caprichos personalistas" que suscitaban "divisiones y capillas", utilizando para ello "medios burgueses, casi masónicos"63. "Falsos comunistas, pseudo dirigentes cuyo mandato no proviene sino de su audacia y sus atropellos", "camarilla nefasta", "capillita inmunda", "grupo de audaces traidores a la causa comunista", "fariseos", "luchadores de salón de la vieja escuela social demócrata quedados rezagados a la vera del camino en la marcha ascendente del proletariado hacia la revolución social", "saboteadores del movimiento proletario y comunista" cuya "inmunda campaña de improperios e intrigas ha colmado todos los límites de la tolerancia", fueron algunos de los epítetos que el periódico hidalguista usó para replicar los ataques laferttistas durante la campaña electoral ${ }^{64}$. La matrona Humilde Figueroa, dirigente de la fracción hidalguista, miembro de uno de los CC del PCCh en la clandestinidad, publicó varios artículos denunciando episodios poco gloriosos de algunos cabecillas de "la capillita de Lafertte y Cía." durante la dictadura, en especial la supuesta tolerancia y connivencia del régimen de Carlos Ibáñez hacia Carlos Contreras Labarca ${ }^{65}$.

El clima de enervamiento que atravesaba a ambas fracciones del comunismo chileno con un telón de fondo de gravísima crisis económica y política en el ámbito nacional, tensionó la campaña a tal punto, que llegaron a producirse algunos enfrentamientos físicos entre partidarios de Lafertte e Hidalgo, como el ocurrido a comienzos de septiembre en un teatro de Santiago cuando un grupo de alrededor de diez laferttistas intentó alterar el acto del senador oposicionista causando un alboroto, distribuyendo panfletos ofensivos y lanzando incluso una pedrada que golpeó al candidato en el momento en que pronunciaba su discurso ${ }^{66}$.

Ambos líderes y sus respectivos comandos recorrieron ciudades y pueblos del norte, centro y sur del país. Lafertte, gracias al natural e irrestricto sostén de la FOCH, obtuvo el apoyo de numerosos obreros del salitre y del carbón, además de sectores de estudiantes universitarios ${ }^{67}$. Hidalgo, por su parte, a través de un organismo denominado Asamblea Nacional Obrera en pro de su candidatura, canalizó la adhesión de: varios gremios de la alimentación, la Unión General de Obreros y Empleados de Chile, obreros municipales, enfierradores, empleados, comerciantes, mineros de Punta de Rieles y Calama, algunos gremios de obreros de la construcción, estudiantes universitarios y jóvenes demócratas disidentes de la posición oficial de su partido organizados en el Centro Demócrata de Santiago ${ }^{68}$.

\footnotetext{
63 "Una circular interesante", en La Chispa, №2, Santiago, agosto de 1931.

64 "La dura verdad proletaria" y Roberto Pinto, "Fariseos en el Partido Comunista", en La Chispa, N², Santiago, agosto de 1931; “iiSaboteadores!!”, en La Chispa, № 3, Santiago, septiembre de 1931.

65 "La valiente y prestigiosa camarada Humilde Figueroa, miembro integrante del C.C. del Partido Comunista, desenmascara a los traidores del proletariado", en La Chispa, N² , Santiago, agosto de 1931.

66 "Los últimos acontecimientos revolucionarios afianzan poderosamente la candidatura del camarada Hidalgo", en La Chispa, N 3, Santiago, septiembre de 1931.

67 "Candidatura de D. Elías Lafertte", en El Mercurio, Santiago, 17 de septiembre de 1931.

68 "La candidatura presidencial de don Manuel Hidalgo", en El Diario Ilustrado, Santiago, 3 de agosto de 1931; "Gran número de universitarios adhiere a la Candidatura del Partido Comunista. Una citación”, en
} 


\section{LA REBELIÓN DE LA MARINERÍA}

La gran recesión generó, entre otras consecuencias, una nueva y explosiva repercusión política poco tiempo después de la caída de Carlos Ibáñez. Ante la persistencia de la crisis, la nueva administración despidió empleados públicos, puso en venta bienes del Estado y anunció una nueva rebaja de los salarios de funcionarios (el exdictador ya lo había hecho un par de ocasiones anteriores). El 28 de agosto, el gobierno anunció recortes de sueldos a los empleados del Estado de un 12\% y 30\% según los niveles de ingresos. Aunque la noticia conmocionó a todas las personas que se verían afectadas por estas disposiciones, la reacción de la marinería de la Armada nacional sorprendió a todo el país. Luego de varias reuniones de oficiales y suboficiales de los barcos de guerra surtos en la bahía de Coquimbo, el 29 de agosto, adelantándose a lo que debía ser una acción general, los cabos del crucero O'Higgins y del destructor Videla presentaron a sus jefaturas una petición de anulación de la medida gubernamental. La reacción intransigente del comodoro Roberto Hozven provocó la ruptura de conversaciones y radicalización del movimiento. La marinería, encabezada por el suboficial Ernesto González (escribiente) y el cabo Manuel Astica (de profesión contador y con cierta experiencia periodística), pasó rápidamente a la acción, constituyendo un organismo denominado Estado Mayor de las Tripulaciones (ETM) con sede en el acorazado Latorre. Durante la noche del 31 de agosto al 1 de septiembre, los marineros apresaron a los oficiales y tomaron el control de los barcos de guerra anclados en Coquimbo. En la tarde del martes 1, el ETM telegrafió al gobierno una proclama cuya principal exigencia era la anulación de la reducción de salarios, dando un plazo de cuarenta y ocho horas para que este emitiera una respuesta satisfactoria a sus exigencias ${ }^{69}$. Aunque los amotinados precisaron que no habían sido influenciados "por ninguna idea de índole anárquica" y que no estaban dispuestos a tolerar "tendencias que entreguen al país en un abismo de desorientación social", también destacaron que jamás, mientras hubiese a bordo un solo individuo de la tripulación, "los cañones de un barco de guerra chileno serán dirigidos contra sus hermanos del pueblo"70.

El alzamiento se extendió como reguero de pólvora a otros puertos y barcos de la Armada: en la noche del 2 al 3 de septiembre, la marinería se apoderó de las naves recaladas en Talcahuano, principal puerto militar del país y las unidades de tierra -artillería de

La Chispa, $\mathrm{N}^{\circ}$ 1, Santiago, 20 de agosto de 1931; "Continúa desarrollándose activamente la propaganda de la candidatura del señor Hidalgo", en El Mercurio, Santiago, 2 de septiembre de 1931; "Una delegación de obreros municipales ofreció su adhesión al Sr. Hidalgo", en El Mercurio, Santiago, 4 de septiembre de 1931; "La candidatura presidencial de don Manuel Hidalgo", en El Diario Ilustrado, Santiago, 11 de septiembre de 1931; "Se intensifican los trabajos electorales de la candidatura del señor Hidalgo", en El Mercurio, Santiago, 17 de septiembre de 1931; "La juventud demócrata proclamó candidato a don Manuel Hidalgo", en El Mercurio, Santiago, 19 de septiembre de 1931; "La juventud demócrata proclamó anoche la candidatura de don Manuel Hidalgo", en El Diario Ilustrado, Santiago, 20 de septiembre de 1931; "Demócratas que apoyan a Hidalgo", en El Diario Ilustrado, Santiago, 24 de septiembre de 1931.

${ }^{69}$ Jorge Magasich A., Los que dijeron "No", Historia del movimiento de los marinos antigolpistas de 1973, Santiago, LOM Ediciones, 2008, vol. I, pp. 149-157.

${ }^{70}$ Patricio Manns, La revolución de la Escuadra, Santiago, Ediciones B, 2001, pp. 48-49; Magasich, op. cit., vol. I, pp. 157-158; Vial, op. cit., vol. v, pp. 34-38. 
costa, Escuela de Mecánicos, puertos militares y obreros del dique- se sumaron al movimiento. Luego, la flota del sur tomó la decisión de dirigirse hacia Coquimbo para unirse a la revuelta. Casi al mismo tiempo, el motín ganó el cuartel Silva Palma y la Escuela de Comunicaciones de Valparaíso, además de la base aérea de Quintero. Por su parte, los soldados del regimiento Arica y los Carabineros de La Serena enviaron una tarjeta de adhesión al movimiento. Ya el 4 de septiembre, las huelgas de mineros del carbón y las manifestaciones estudiantiles habían semiparalizado la región de Concepción ${ }^{71}$.

Así fue como el país se vio envuelto en un clima febril y distintos actores intentaban intervenir en la crisis: en las esferas dirigentes y gubernamentales se enfrentaron dos posiciones, una más conciliadora, partidaria del diálogo y de algunas concesiones que pusieran término a una rebelión que podría convertirse en una amenaza seria para el orden social versus los partidarios de la "mano dura", represión pura y simple para aplastar la sublevación. Esta última postura, finalmente, terminó imponiéndose. La izquierda también quiso incidir en el curso de los acontecimientos: las fracciones comunistas, embarcadas en la campaña electoral y en una dura competencia entre sí, intentaron desarrollar cada una su propia política en función de la coyuntura.

Cerca de la medianoche del martes 1 de septiembre, en el palacio de La Moneda se reunieron el Vicepresidente de la República, Manuel Trucco, sus ministros, el presidente del Senado y connotados políticos de diversos partidos, entre ellos, Arturo Alessandri Palma, Ladislao Errázuriz y el comunista disidente Manuel Hidalgo, a fin de intercambiar informaciones e ideas sobre la crisis desatada por el levantamiento en la Armada. Si bien El Mercurio de Santiago informó que Elías Lafertte había participado en la reunión, esto fue terminantemente desmentido por el propio dirigente en carta dirigida al mismo órgano de prensa ${ }^{72}$. El 4 de septiembre la fracción laferttista envió tres delegados de la FOCH a ofrecer su apoyo a los amotinados del puerto de Coquimbo y a solicitarles, según atestiguaría Ernesto González, "ampliar los puntos de vista" de la proclama, integrando las demandas de todos los hambrientos y exigiendo en forma decidida un cambio de régimen social. González habría agradecido el apoyo prestado y respondido que el movimiento terminaría esa tarde, que los marineros no eran partidarios de la revolución social y que retomarían contacto con los fochistas en caso de ser necesario. De dar fe a este testimonio emanado de uno de los principales líderes de la revuelta (quien, a la postre, derivaría en simpatizante comunista), la tentativa del comunismo ortodoxo por cooptar el motín espontáneo de las tripulaciones habría fracasado en el momento mismo de su gestación ${ }^{73}$. Al contrastar esta versión de los hechos con los informes despachados al BSA por "Juárez" (es probable que se trate de Paulino González Alberdi), delegado de la Internacional que por aquellos días se encontraba en Chile, se puede concluir con bastante certeza que, contrariamente a las interpretaciones que atribuyeron a los comunistas un papel central en la preparación y ejecución de la insurrección de la marinería, ambas fracciones del PCCh fueron en absoluto ajenas a su estallido, aunque durante su desarrollo intentaron incidir en el curso de los acontecimientos según con sus respectivas estrategias. Esa fue, también, la impresión del almirante Edgardo Von Schröders, enviado del

\footnotetext{
${ }^{71}$ Magasich, op. cit., vol. I, pp. 158-159; Vial. op. cit., vol. v, pp. 42-47.

${ }^{72}$ Citado en Manns, op. cit., p. 68.

${ }^{73}$ Magasich, op. cit., vol. I, p. 168.
} 
Ejecutivo para negociar con los insurrectos, quien en un radiograma enviado al ministro de Marina el 3 de septiembre, sostuvo que el movimiento parecía "no tener raigambre política ni comunista", si bien poco después matizó su juicio al afirmar que la influencia comunista sobre las tripulaciones venía, sin duda alguna, de Talcahuano, "donde en su numeroso personal obrero, y aun en civiles de la población, estas disolventes teorías siempre han existido, y en los últimos tiempos solo se encontraban adormecidas debido a la mano fuerte del Gobierno [de Carlos Ibáñez]”, para, con posterioridad, una vez superada la crisis, afirmar con mucha seguridad en un informe secreto remitido al mencionado Ministro, que "a pesar del giro francamente comunista que poco a poco fue tomando el amotinamiento de la Escuadra", estaba convencido que se había originado por causas económicas, que la gran mayoría de las tripulaciones de la Escuadra eran "sanas" y que tampoco estaban contaminadas con esas "nefastas teorías"74.

Paralelamente a estos hechos, en Valparaíso, los activistas del laferttismo, entre ellos Juan Chacón, intentaban un acercamiento con soldados y suboficiales del Ejército, la Armada y la policía, logrando establecer algunos contactos con el cuartel de Las Zorras, la $4^{a}$ Comisaría de Carabineros, artilleros, el regimiento Coraceros y otras unidades, a fin de incitar a los uniformados a marchar sobre Santiago, distribuir armas al pueblo y derrocar al gobierno, pero estos no se decidieron a emprender tal acción ${ }^{75}$.

El 9 de septiembre, "Juárez" escribió una carta al BSA dando cuenta pormenorizada -día por día- de los hechos relacionados con el levantamiento en la Armada. Según su relato, en la tarde del 1 de septiembre, durante el curso de capacitación que impartía a los cuadros del partido chileno, Lafertte le comunicó que camaradas llegados de Coquimbo le habían informado acerca de los preparativos de una rebelión en la Escuadra, lo que da cuenta de la existencia de simples contactos entre sectores de la marinería y algunos comunistas en ese puerto. "Los marinos se preparan y mantienen los vínculos con los compañeros del partido. Pero ellos no hablaron de la insurrección como de una empresa tan cercana", escribió "Juárez", reflejando la no injerencia directa del PCCh en la preparación del alzamiento ${ }^{76}$. Hecho que es refrendado en el testimonio autobiográfico de Elías Lafertte, donde relata que el 1 de septiembre llegó a Santiago un compañero de apellido Lobos, enviado desde Coquimbo por Rufino Rosas, con la noticia de los preparativos del motín, sin embargo, la dirección del partido no pudo adoptar rápidas medidas de apoyo puesto que, por razones desconocidas, los marineros adelantaron su movimiento que estalló ese mismo día ${ }^{77}$. "Juárez", por su parte, relató en la misma misiva que el miércoles 2 de septiembre, el Buró Político y el CC de la fracción laferttista decidieron declarar una huelga de solidaridad con los marinos y para luchar por la reivindicaciones del partido sin distingo entre consignas inmediatas y de largo plazo, acordándose también el envío urgente de un miembro del Buró Político a Valparaíso y otro integrante de ese organismo al día siguiente a Coquimbo con instrucciones precisas (sin indicar en

\footnotetext{
${ }^{74}$ Citado en Manns, op. cit., pp. 88, 102 y 206.

${ }^{75}$ José Miguel Varas, Chacón, Santiago, Sociedad Impresora Horizonte Ltda., 1968, p. 74.

76 "Carta del representante del Profintern desde Chile al Buró Sudamericano. 09.09.1931", RGASPI, 534.4.399, en Ulianova y Riquelme (editores), op. cit., tomo 2, p. 87.

${ }^{77}$ Lafertte, op. cit., p. 229.
} 
qué consistían dichas directrices). Luego partiría un tercero a Concepción ${ }^{78}$. Para desatar en Santiago la huelga general en apoyo a los marineros, Elías Lafertte, Carlos Contreras Labarca, Luis Víctor Cruz, el joven Marcos Chamúdez y otros cuadros del partido fueron enviados a una reunión de los tranviarios santiaguinos, en la que debían discutirse los pasos a seguir del movimiento reivindicativo que estaban desarrollando. Según "Juárez", los activistas del partido "causaron animación en la reunión e indujeron a los participantes a empezar de inmediato la huelga y declarar su solidaridad con los marinos"79. Lafertte afirma en sus memorias que los tranviarios, al principio, se oponían a ir a la huelga, pero que después de "una larga, difícil y enconada discusión", cedieron, lo que refleja el carácter un tanto forzado que tuvo el paro bajo la presión de los cuadros comunistas, cuestión que repercutiría al día siguiente ${ }^{80}$.

La huelga se llevó a cabo, efectivamente, en Santiago, Valparaíso y otras ciudades el jueves 3 de septiembre, sin alcanzar la amplitud que el delegado komintereano describió en su informe al BSA. Según "Juárez", ese día se había producido "una total paralización", Santiago daba una impresión de "paralización total de los trabajos", provocándose "una amplia movilización de las fuerzas" con "grandes masas de gente en las calles", "a pesar de la ausencia aquí de las organizaciones de base tanto del partido como de la Federación Obrera de Chile" ${ }^{\text {. }}$. En realidad, el aspecto de parálisis de la capital descrito en este documento se debió a las dificultades en el transporte público provocadas por la huelga de los tranviarios, ya que los gremios de otros sectores que adhirieron a la movilización no fueron muy numerosos, aunque en algunos casos obtuvieron satisfacción de ciertas demandas. Lafertte, más mesurado, cuenta en su autobiografía que, "en algunos aspectos, la huelga fue total, como por ejemplo, en la locomoción. No salió un solo tranvía a trabajar, y varias carretas y carretones de pan y de vino, fueron volcados en las calles" ${ }^{2}$. Como reconoció "Juárez", la propia FOCH y las organizaciones de base del partido tuvieron escasa presencia en la implementación del paro, recayendo, con certeza, el grueso del trabajo en un reducido número de cuadros que desplegaron una intensa actividad. El comité de huelga, integrado por representantes de trabajadores de varias empresas, presidido por Elías Lafertte, funcionó unas pocas horas. Después del almuerzo -informó "Juárez"- "de hecho no trabajaba y se disolvió". Las divisiones en el seno de los tranviarios -entre los partidarios de continuar el paro y los que deseaban terminarlo- además de la protección policial puesta por el gobierno a los tranvías que empezaron a circular esa misma tarde, llevaron a los propios comunistas a decretar el

\footnotetext{
${ }^{78}$ Es preciso recalcar que en esta carta, al igual que en otras de los delegados de la Internacional para Chile, queda absolutamente claro el rol directivo de dichos emisarios: "decidimos declarar una huelga de solidaridad...", "acordamos que al día siguiente...", etc., son expresiones inequívocas que reflejan que "Juárez" -del mismo modo como los anteriores missi dominici komintereanos- no era un simple comisionado fraternal portador de ayuda material o simbólica, sino un agente plenipotenciario encargado de conducir hasta en cuestiones de detalle al partido chileno, gracias a su doble calidad de integrante de pleno derecho de sus máximos organismos dirigentes y, al mismo tiempo, enviado del BSA.

79 “Carta del representante del Profintern desde Chile al Buró Sudamericano. 09.09.1931”, op. cit., p. 88.

${ }^{80}$ Lafertte, op. cit., p. 231.

81 "Carta del representante del Profintern desde Chile al Buró Sudamericano. 09.09.1931”, op. cit., pp. 88-89.

${ }^{82}$ Lafertte, op. cit., p. 222.
} 
fin de la huelga ${ }^{83}$. Esta debilidad manifiesta no impidió que al día siguiente la FOCH anunciara con aire triunfal que su Junta Ejecutiva había dado por terminada la huelga general "por haberse cumplido el objetivo fundamental de ella, es decir, el de efectuar una gran demostración revolucionaria como expresión de solidaridad hacia los marineros sublevados en Coquimbo". El establecimiento de conversaciones entre el gobierno y los marineros insurrectos fue el argumento dado por la central sindical laferttista para deponer el paro, aunque manifestó sus reparos por la decisión del gremio de tranviarios, "bajo la presión de sus dirigentes", de concluir su movimiento sin tener la seguridad de haber obtenido plena satisfacción a sus reivindicaciones. No obstante este reproche, la directiva de la FOCH declaró que el objetivo estaba cumplido al asegurar los tranviarios que retomarían sus acciones si no lograban pleno éxito, atenuando la tensión provocada por su pretensión de radicalizar un movimiento esencialmente reivindicativo ${ }^{84}$.

Durante estos días, la fracción hidalguista del PCCh desarrolló una política acorde con su concepción más amplia de alianzas y de frente único obrero. De acuerdo con un balance realizado un par de meses más tarde por los dirigentes del Comité Regional de Aconcagua y Santiago, reiterado y ampliado en la Conferencia Nacional que en marzo de 1933 dio origen a la Izquierda Comunista, a comienzos de septiembre de 1931 los comunistas opositores al laferttismo y al BSA crearon un comité revolucionario de frente único obrero integrado, entre otros, por sus propios militantes, anarquistas, Frente Único Sindical, algunas ligas de arrendatarios de varias comunas, una cuantas organizaciones obreras aisladas, tranviarios, ferroviarios de Santiago y de San Bernardo, el Partido Socialista Marxista y delegados de la fábrica de papel de Puente Alto. Este comité se sumó al paro impulsado por los laferttistas, se apoderó de autobuses y automóviles para el desplazamiento de sus activistas a distintos puntos de la ciudad, incluyendo el envío de delegaciones a las comisarías para agitar a la tropa y a la suboficialidad, distribuyó propaganda y planificó la toma de locales, imprentas, armerías, almacenes, además de sentar "las bases para los comités de barrios, génesis de los soviets", proyecto abortado por los ataques de militares, guardias blancas, carabineros y por la declaración del estado de sitio $^{85}$. Siguiendo esta idea del frente único, los hidalguistas, incluso, enviaron representantes para proponer a los laferttistas unir fuerzas, recibiendo un violento rechazo de sus camaradas rivales ${ }^{86}$, si bien según el testimonio del propio emisario del BSA, en las filas del laferttismo hubo militantes "con ánimos conciliadores" quienes consideraban que, dadas las condiciones, no se debía atacar a los hidalguistas ${ }^{87}$.

Mientras ocurrían estos hechos en la capital, el gobierno se decidía a aplastar el movimiento de la marinería. En los días siguientes -sábado 5 y domingo 6- fueron atacados y vencidos por el Ejército y la Fuerza Aérea, los rebeldes en Coquimbo, Valparaíso

83 “Carta del representante del Profintern desde Chile al Buró Sudamericano. 09.09.1931”, op. cit., pp. $89-90$.

84 “La Foch y la huelga general”, en La Bandera Roja, Santiago, Manifiesto N 4 de septiembre de 1931.

${ }^{85} \mathrm{AHN}, \mathrm{FMH}$, Informe del Comité Regional al Congreso Regional de Aconcagua y Santiago [noviembre de 1931], fjs. 10 y 11, sin catalogar; En defensa de la revolución. Informes, tesis y documentos presentados al Congreso Nacional del Partido Comunista a verificarse el 19 de marzo de 1933, Santiago, Editorial Luis Emilio Recabarren, 1933, pp. 44-45.

${ }^{86}$ En defensa de la revolución..., op. cit., p. 45.

87 “Carta del representante del Profintern desde Chile al Buró Sudamericano. 09.09.1931”, op. cit., p., 89. 
y Talcahuano, con un costo muy elevado de víctimas (probablemente varios centenares de muertos y heridos $)^{88}$. Sin entrar en el detalle de estos hechos ni en el análisis de las causas de la derrota de los marineros -cuestión que escapa a los objetivos de este artículo- es preciso destacar que mientras el PCCh "oficial", basado solo en sus propias fuerzas, intentó radicalizar el movimiento de las tripulaciones de la Armada para llevarlo a posiciones "revolucionarias" y luego del fracaso del paro general, se abocó a la formación de raquíticos "soviets" de barrio en la capital (según el propio "Juárez", a la reunión preparatoria realizada el 7 de septiembre, concurrieron veintinueve militantes del partido y veintiuno que no lo eran ${ }^{89}$ ), la fracción hidalguista trató de implementar una política de alianzas de fuerzas obreras y de izquierda más amplia, incluyendo a los miembros de la facción rival. No obstante, ninguno de estos grupos logró desarrollar una política a la altura de las circunstancias. Según el balance de los hidalguistas, aunque en Talcahuano, Valparaíso y Coquimbo hubo apoyo de masas al movimiento de los marineros, el PCCh demostró su incapacidad de comportarse como vanguardia del proletariado, entre otras razones, por su falta de base en los sectores más importantes de la producción (salitre, carbón, cobre, transporte, alimentación, agricultura), además de su carencia de trabajo en las filas de las Fuerzas Armadas y Carabineros. Ello habría imposibilitado ganar el apoyo de las grandes masas trabajadoras al movimiento de la Marina, darle proyección política y ampliarlo a una lucha armada de clases. De todos modos, los hidalguistas se sumaron al paro impulsado por los laferttistas ${ }^{90}$.

Por su parte, el delegado del BSA también reconoció la debilidad del PCCh, su incapacidad para prolongar la huelga en Santiago más allá de veinticuatro horas y para desenmascarar las maniobras de los líderes reformistas ${ }^{91}$. Más tarde, el mismo BSA en sus Tesis sobre las grandes luchas del proletariado chileno, develó la nula ligazón del movimiento con el PCCh por la inexistencia de bases propias en la Marina y hasta por ausencia de propaganda previa del partido, lo que redundó en vacilaciones y errores de conducción de la insurrección que la llevaron a la derrota. El BSA también culpó al partido chileno, "pese a la gran actividad y espíritu combativo durante el movimiento", por su incapacidad para "resolver el problema principal de la estrategia: organización de la lucha de masas e impedir al enemigo organizar sus fuerzas"

"En lugar de esto lanzó la consigna de toma del poder local por los marinos sublevados y de la formación inmediata de los consejos. El Partido mostró así, falta de táctica y de sentido real de situación. En lugar de ampliar paso a paso nuestras consignas, pasando de las parciales a las más amplias, de acuerdo al desarrollo del movimiento y a la encarnación de esas consignas en las masas mismas, el partido, desde el principio del movimiento, empezado sin ninguna

${ }^{88}$ Magasich, op. cit., vol. I, pp. 171-177; Vial, op. cit., vol. v, pp. 49-70.

89 “Carta del representante del Profintern desde Chile al Buró Sudamericano. 09.09.1931”, op. cit., p. 93.

${ }^{90}$ En defensa de la revolución..., op. cit., pp. 45-46.

91 "Carta del representante del Profintern desde Chile al Buró Sudamericano. 09.09.1931”, op. cit., p. 94.

92 "Las grandes luchas del proletariado chileno (tesis del B.S.A. de la I.C.)", en Revista Comunista, año II, $\mathrm{N}^{\circ} 6$, Montevideo, noviembre de 1931, pp. 10-40. Para efectos prácticos citaremos la siguiente reproducción, de más fácil acceso: "Tesis del Buró Sudamericano de la Internacional Comunista sobre las grandes luchas del proletariado chileno. 04.12.1931”, RGASPI, 495.106.26, en Ulianova y Riquelme (editores), op. cit., tomo 2, pp. 122-125. 
ligazón con el partido, lanzó la consigna de formar los soviets como consigna de movilización de las grandes masas. Esta consigna, apropiada para una fase superior de este movimiento no servía al comienzo del mismo. El Partido, sin comprender la etapa del movimiento en que se encontraba y acercarse a la masa con consignas que esta sostuviera, poniéndose sí a su cabeza, partió de la concepción falsa de que la revolución agraria antiimperialista era un hecho, aún sin la dirección del partido"93.

Resulta interesante constatar como el BSA criticó los errores "de izquierda" característicos de la política de "clase contra clase" cometidos por "su partido" chileno, yerros en los que tuvo activa participación "Juárez", su hombre de confianza encargado de velar por la adecuada implementación de la línea de la Internacional. Similares críticas al izquierdismo del PCCh fueron formuladas en el mismo documento a propósito de la exótica y endeble tentativa de construcción de "soviets" en septiembre de 1931. El partido, se sostiene en estas tesis, sin considerar las condiciones en que se produjo la sublevación de la marinería, en lugar de realizar una propaganda enérgica por el establecimiento de los consejos, sin explicar su contenido ni programa, actuó como si la revolución fuese ya un hecho, lanzó la consigna de la inmediata creación de soviets "y llamó a los marineros a tomar el poder y a constituir el poder soviético local", saldándose esta política en un fracaso, ya que estos se negaron a organizar los soviets. Solo en Santiago -que no constituía un punto fundamental del movimiento y el partido era menos influyente que en otros lugares- se formaron consejos que, como el mismo partido lo estableció después, "no pasaron de ser órganos de frente único", que permitieron que el partido entrara en contacto con las masas, pero -según este análisis- "no podían considerarse verdaderos órganos de expresión de la masa de luchar por el poder", además, de haber sido constituidos en el "período descendiente de la lucha", motivo por el que, en lugar de ampliar el frente de lucha y permitir la ligazón con los marineros, habían sido un "factor de debilitamiento para la formación de un amplio frente único de las masas por sus reivindicaciones" 94 .

\section{CierRe de Las CAMPaÑas Electorales COMUNistas}

El 3 de septiembre fue declarado el estado de sitio. La movilización de tropas del Ejército y de la Fuerza Aérea para aplastar a los marineros sublevados, fue acompañada de medidas restrictivas de las libertades públicas que durante algunos días repercutieron de manera negativa en las campañas electorales de ambas fracciones comunistas. Varios dirigentes de la fracción oficialista-komintereana -entre ellos el propio candidato Elías Lafertte- fueron buscados por la policía, debiendo esconderse y desvincularse momentáneamente de la dirección del partido que quedó reducida a tres personas: Contreras Labarca, Marcos Chamúdez y "Juárez". Por otro lado, en Illapel, Ovalle y Mulchén fueron clausurados periódicos partidarios de Manuel Hidalgo y en Illapel, Ovalle, Viña

93 "Tesis del Buró Sudamericano de la Internacional Comunista sobre las grandes luchas del proletariado chileno. 04.12.1931”, RGASPI, 495.106.26, en Ulianova y Riquelme (editores), op. cit., tomo 2, pp. 125-126.

94 “Tesis del Buró Sudamericano...", op. cit., p. 129. 
del Mar, Valparaíso, Santiago y San Rosendo fueron arrestados varios activistas de su campaña siendo liberados al cabo de algunos días ${ }^{95}$. Con todo, la situación se normalizó rápidamente y a partir de la segunda semana de septiembre, contando con la promesa gubernamental de garantizar la libertad electoral, las candidaturas comunistas continuaron sus trabajos, al igual que las de Montero y Alessandri Palma ${ }^{96}$.

Hidalgo debió hacer frente a insistentes e interesados rumores acerca de deponer su postulación a favor de Alessandri, quien sería presentado por su conglomerado como el "candidato de las izquierdas". El Comité Central de la campaña hidalguista publicó una declaración en la que reafirmaba su firme decisión de competir en las urnas el 4 de octubre, ya que representaba a "las verdaderas fuerzas izquierdistas y trabajadoras del país"97. Uniendo la acción a la palabra, el senador comunista y sus partidarios redoblaron el trabajo electoral realizando actos públicos en distintas localidades: el 12 de septiembre partió en gira al sur, siendo Talca la primera ciudad visitada, el 15 una delegación de su comando participó en un acto en Illapel, el 20 el candidato se presentó en el teatro Palace de Valparaíso ${ }^{98}$, el 23 sus seguidores proclamaron la candidatura en Calama y Chuquicamata ${ }^{99}$, el 25 el propio Hidalgo habló en un meeting en Viña del Mar y, al día siguiente, se dirigió nuevamente al sur para participar en sendos actos en Concepción, Tomé y Chillán ${ }^{100}$. Por último, a comienzos de octubre, cerrando la campaña, delegaciones de su comando se hicieron presentes en manifestaciones en Taltal, La Ligua, Llo-Lleo, Barrancas, Antofagasta, Rancagua y Talca. Como broche de oro, en las semanas previas a la elección, algunos intelectuales de renombre, como los escritores Augusto Iglesias M., Eugenio Orrego Vicuña y, desde Francia, el poeta Vicente Huidobro, anunciaron su apoyo al senador ${ }^{101}$.

Elías Lafertte, por su parte, se dirigió a la zona del carbón en la segunda quincena de septiembre, a fin de asistir a proclamaciones en Lota, Coronel, Concepción y otras localidades $^{102}$. El paso del tren en que viajaba fue ocasión para que sus partidarios acudieran

95 "Carta del representante del Profintern desde Chile al Buró Sudamericano. 09.09.1931”, op. cit., pp. 9094; Lafertte, op. cit., p. 232; "Diarios clausurados y compañeros presos", en La Chispa, № 2, Santiago, agosto de 1931.

96 "Se intensifican los trabajos en pro de la candidatura del Sr. Hidalgo", en El Mercurio, Santiago, 9 de septiembre de 1931.

97 "La candidatura de don Manuel Hidalgo no admite ninguna transacción”, en El Mercurio, Santiago, 20 de septiembre de 1931.

${ }_{98}$ Ibid.; "Hidalgo sale hoy en jira al sur", en El Mercurio, Santiago, 12 de septiembre de 1931; "Se intensifican los trabajos electorales de la candidatura del señor Hidalgo", en El Mercurio, Santiago, 17 de septiembre de 1931; "Ayer fue proclamado el señor Manuel Hidalgo en Valparaíso", en El Mercurio, Santiago, 21 de septiembre de 1931.

99 "El candidato izquierdista señor Hidalgo fue proclamado ayer en Chuquicamata", en El Mercurio, Santiago, 24 de septiembre de 1931; "Los trabajos electorales de la candidatura M. Hidalgo", en El Diario Ilustrado, Santiago, 24 de septiembre de 1931.

100 "El Candidato don Manuel Hidalgo partió anoche en gira al sur del país", en El Diario Ilustrado, Santiago, 27 de septiembre de 1931.

101 "Continúa proclamándose al Sr. Hidalgo en distintos pueblos de la República”, en El Mercurio, Santiago, 1 de octubre de 1931; "Las fuerzas izquierdistas de Ligua proclaman la candidatura de Hidalgo", en El Diario Ilustrado, Santiago, 2 de octubre de 1931; "Últimas actividades de la candidatura de don Manuel Hidalgo", en El Diario Ilustrado, Santiago, 4 de octubre de 1931.

102 "Proclamación del candidato Lafertte", en El Mercurio, Santiago, 30 de septiembre de 1931. 
a vitorearlo en las estaciones de Talca, Chillán y otras localidades ${ }^{103}$. En Osorno la manifestación de su candidatura no pudo terminarse porque fue interrumpida por la policía, provocando la protesta de su partido ${ }^{104}$. La fracción comunista seguidora del BSA puso especial énfasis en Valparaíso, ciudad hasta donde se desplazaron los miembros del CC, realizando, según la evaluación de los propios dirigentes chilenos, un buen trabajo ${ }^{105}$. En Santiago, en cambio, el Comité Regional del partido llamó la atención a sus militantes acerca de la "ninguna actividad" para dar a la campaña el "significado de movilización de masas" que debía tener, vinculando las reivindicaciones populares con el programa de su candidato, reprochándoles también su falta de energía para señalar "el papel confusionista y de traición" representado la candidatura de Manuel Hidalgo ${ }^{106}$. Culminando la campaña, la tarde de la víspera de la elección, se efectuaron en la capital sendas reuniones de jóvenes y mujeres que apoyaban esta candidatura ${ }^{107}$. Aunque las últimas no tenían derecho a voto, se concertaron para recorrer los locales de votación el día de la elección a fin de proporcionar a los apoderados de su candidato los votos y demás útiles necesarios para el cumplimiento de su misión ${ }^{108}$. La tarde del mismo sábado 3 de octubre, Elías Lafertte, acompañado de su camarada Carlos Contreras Labarca, visitó el diario La Segunda de las Últimas Noticias para desmentir la información falsa relacionada con su supuesto retiro de la carrera presidencial en beneficio de Arturo Alessandri. Al día siguiente, antes de que los resultados de la elección fueran oficialmente proclamados, el candidato del comunismo oficial partió en el tren trasandino en dirección de Buenos Aires, para continuar a Montevideo a fin de participar en una reunión de la Confederación de Sindicatos Latinoamericanos (CSLA) dependiente del Profintern y dictar algunas conferencias ${ }^{109}$.

\section{LOS RESULTADOS ELECTORALES Y EL BALANCE DE LAS FRACCIONES}

La vasta alianza "civilista" sobre la que basó su candidatura, aseguró una holgada victoria a Juan Esteban Montero, quien obtuvo 182.177 sufragios (63,93\%), contra 99.075 (34,77\%) de Arturo Alessandri Palma, apenas 2.434 (0,86\%) de Elías Lafertte y 1.263 $(0,44 \%)$ de Manuel Hidalgo. La abstención alcanzó 26,52\% de los inscritos. "El León”, al igual que en la década anterior, arrebató a los comunistas una parte sustantiva de su

${ }^{103}$ Luis Corvalán, a la sazón adolescente de solo quince años de edad, y más tarde secretario general del PCCh, anotó en sus memorias, en forma de brevísimo testimonio personal, el saludo que un centenar de personas dieron a Elías Lafertte en su parada en la estación de Chillán. Luis Corvalán, De lo vivido y lo peleado. Memorias, Santiago, LOM Ediciones, 1999, p. 19.

104 "El candidato señor Lafertte", en El Mercurio, Santiago, 1 de octubre de 1931.

105 “Carta del PC chileno al Buró Sudamericano de KOMINTERN. 24.10.1931”, RGASPI, 495.106.25, en Ulianova y Riquelme (editores), op. cit., tomo 2, p. 99.

${ }^{106}$ Boletín de Instrucciones e Informaciones, $\mathrm{N}^{\circ}$ 1, Santiago, 21 de septiembre de 1931, Partido Comunista de Chile, Internacional Comunista, Comité Regional, en AHN, FIS, Comunicaciones recibidas $\mathrm{N}^{\circ} 4503$ 4700, octubre de 1931, vol. 792, documento adjunto al oficio N4820 del coronel y prefecto jefe Bruno Montt Polanco a la Intendencia de la provincia, Santiago, 29 de noviembre de 1931, doc. N 4643, fjs. 1-6.

107 "La candidatura comunista de Elías Lafertte", en El Mercurio, Santiago, 3 de octubre de 1931.

108 "Los comunistas lucharán hoy por su candidato don Elías Lafertte", en El Mercurio, Santiago, 4 de octubre de 1931.

${ }^{109}$ Lafertte, op. cit., p. 234. 
electorado "natural". Si bien Montero triunfó en todas las provincias, Alessandri alcanzó la mayoría en el Norte Grande (Tarapacá y Antofagasta) obteniendo 57,4\% contra 3,2\% de Lafertte (su mejor resultado en todo el país) y $0,5 \%$ de Hidalgo. Excepto la región salitrera, los comunistas de ambas fracciones consiguieron sus más altas votaciones en Santiago, Concepción, algunos puertos y los distritos mineros de la cuenca del carbón en el sur, destacándose además el 0,9\% obtenido por Lafertte en La Frontera, porcentaje levemente superior a su promedio nacional. El único lugar donde Hidalgo sobrepasó a Lafertte fue Santiago, plaza fuerte del senador disidente desde los primeros tiempos de su militancia en el POS. El siguiente cuadro, elaborado por Paul Drake da cuenta detallada de estos resultados por macrorregiones, englobando cada una de ellas varias provincias.

CuAdro 1

\begin{tabular}{lcccc}
\hline \multicolumn{1}{c}{ Región } & $\begin{array}{c}\text { Juan Esteban } \\
\text { Montero }\end{array}$ & $\begin{array}{c}\text { Arturo } \\
\text { Alessandri Palma }\end{array}$ & $\begin{array}{c}\text { Elías } \\
\text { Lafertte }\end{array}$ & $\begin{array}{c}\text { Manuel } \\
\text { Hidalgo }\end{array}$ \\
\hline Norte Grande & $38,6 \%$ & $57,4 \%$ & $3,2 \%$ & $0,5 \%$ \\
Norte Chico & $72,5 \%$ & $25,7 \%$ & $1,0 \%$ & $0,3 \%$ \\
Centro Urbano & $60,4 \%$ & $37,7 \%$ & $0,8 \%$ & $0,8 \%$ \\
Centro Norte & $71,9 \%$ & $27,5 \%$ & $0,3 \%$ & $0,1 \%$ \\
Centro Sur & $83,9 \%$ & $15,9 \%$ & $0,0 \%$ & $0,1 \%$ \\
La Frontera & $67,2 \%$ & $31,7 \%$ & $0,9 \%$ & $0,0 \%$ \\
Los Lagos & $76,3 \%$ & $23,3 \%$ & $0,3 \%$ & $0,0 \%$ \\
Total & $63,8 \%$ & $34,7 \%$ & $0,8 \%$ & $0,4 \%$ \\
\hline
\end{tabular}

Fuente: Drake, op. cit., p. 52.

El cuadro 2 (elaborado por Julio Pinto y Verónica Valdivia) refleja con más detalle las votaciones obtenidas por todos los candidatos en cuatro provincias con alta concentración proletaria (las cifras expresan cantidades de votos).

CUAdRo 2

\begin{tabular}{lcccc}
\hline Provincia & $\begin{array}{c}\text { Juan Esteban } \\
\text { Montero }\end{array}$ & $\begin{array}{c}\text { Arturo } \\
\text { Alessandri Palma }\end{array}$ & $\begin{array}{c}\text { Elías } \\
\text { Lafertte }\end{array}$ & $\begin{array}{c}\text { Manuel } \\
\text { Hidalgo }\end{array}$ \\
\hline Tarapacá & 1.953 & 5.542 & 163 & 6 \\
Antofagasta & 4.794 & 5.667 & 452 & 104 \\
Santiago & 38.832 & 28.928 & 392 & 493 \\
Concepción & 13.042 & 7.480 & 379 & 90 \\
\hline
\end{tabular}

Fuente: Julio Pinto V. y Verónica Valdivia O., ¿Revolución proletaria o querida chusma? Socialismo y Alessandrismo en la pugna por la politización pampina (1911.1932), Santiago, LOM Ediciones, 2001, p. 120 .

Los balances de estos resultados dados a conocer por las dos fracciones que se disputaban la representación del comunismo chileno, difirieron radicalmente de acuerdo 
con sus opuestas orientaciones políticas. En el bando oficialista, el análisis definitivo lo hizo -como solía ocurrir- el BSA en Montevideo. Dos meses exactos después de las elecciones, este organismo publicó sus tesis sobre Chile en las que dedicó algunos pasajes a la reciente justa electoral por la Presidencia de la República. La "cantidad pequeña de votos para el partido" fue explicada, en parte, por la acción de los reaccionarios que había impedido al partido chileno hacer propaganda, por el robo descarado de sufragios y por el alejamiento de los obreros cesantes de sus lugares de inscripción, factor que les habría imposibilitado acudir a sus lugares de votación. También se señala en este documento que la feble cantidad de preferencias marcadas por Lafertte se explicaba por las "vacilaciones habidas en el seno del partido frente a las corrientes pequeñoburguesas (hidalguistas, etc.) y que han facilitado a esas realizar su obra de confusionismo". Del mismo modo, habrían pesado de manera negativa "la lucha insuficiente contra el alessandrismo que ha podido así concebir ilusiones democráticas a las masas y la creencia de que Alessandri es mejor que Montero", haciendo que muchos obreros simpatizantes comunistas votaran por el primero ${ }^{110}$. Como último elemento, el BSA señaló en su análisis la carencia de una campaña electoral organizada como tal por las reivindicaciones inmediatas de las masas y el escaso vínculo de esta campaña con "las grandes actividades en que ha intervenido el Partido (huelgas, Convención FOCH, etc.)”. Con todo, las Tesis del BSA recogieron como elemento positivo la reacción enérgica del partido, "reclutando nuevos obreros y haciendo una demostración revolucionaria en Concepción y Valparaíso, como lo había hecho en Santiago con las candidaturas de obreros y marinos, condenados por la sublevación de la escuadra" "111.

Un primer balance del hidalguismo acerca de los resultados electorales fue formulado por su propio candidato derrotado pocos días después de conocidos los cómputos definitivos. En una entrevista periodística, Hidalgo explicó que sus magros resultados se debían, en primer lugar, a la "campaña de engaños" que había desarrollado el alessandrismo, anunciando profusamente que su candidatura se había retirado, plegándose a favor de "el León", cuestión que hizo que muchos de sus partidarios votaran por Alessandri. Por otra parte, la sublevación de la marinería había generado un sentimiento de reacción en el país, cerrándose las puertas de la prensa a la propaganda hidalguista e infundiendo temor en el electorado de clases medias afectadas por la crisis económica. Este hecho había servido de pretexto para decretar el Estado de sitio y suspender las libertades en todo Chile, lo que había redundado en persecución de los comités de propaganda, clausura de órganos de prensa y detención en Antofagasta de veintitrés dirigentes de su campaña que fueron relegados a Arica ${ }^{112}$.

\footnotetext{
110 “Tesis del Buró Sudamericano...”, op. cit., p. 143. Un fenómeno similar se había producido en la elección presidencial de 1920 cuando el Partido Obrero Socialista (antecesor directo del PCCh), para hacer frente a la marea alessandrista, había levantado, con escasísimo éxito, la candidatura simbólica de su líder Luis Emilio Recabarren, quien se encontraba en prisión. Véase Grez, Historia del comunismo..., op. cit., pp. 105-121; Pinto y Valdivia, op. cit., pp. 67-68; Julio Pinto V., Luis Emilio Recabarren. Una biografía histórica, Santiago, LOM Ediciones, 2013, pp. 187-191.

111 “Tesis del Buró Sudamericano...”, op. cit., p. 143.

112 "Hidalgo y sus 1.343 votos", en Sucesos, Santiago, 22 de octubre de 1931.
} 
Con más detención, el Comité Regional de Aconcagua y Santiago del partido hidalguista analizó estos hechos en un congreso regional realizado en noviembre del mismo año, concluyendo con bastante perspicacia que la elección había demostrado que "el Partido Comunista y la radicalización de las masas son dos cosas absolutamente independientes" si el partido mantenía una política "permamentista" [sic], o sea, "que sostiene la creencia de que el tiempo pasa y los hechos no alteran la realidad". Era necesario asumir que la dictadura de Carlos Ibáñez había destruido al partido, las organizaciones revolucionarias de masas y, por lo tanto, los contactos entre ambos. Los comunistas no se habían percatado a tiempo de estos cambios, sostuvieron de manera autocrítica los autores del informe presentado en esta reunión: "necesitamos una campaña presidencial para constatar que el partido no era la vanguardia revolucionaria del proletariado que todos creíamos" $" 113$.

El balance hecho en marzo de 1933 con motivo del Congreso en que la fracción hidalguista se transformó en Izquierda Comunista, profundizó un poco más las explicaciones de las causas de la derrota. De manera descarnada, en el informe presentado en esa oportunidad se planteó que la campaña electoral había demostrado "el descreimiento de la influencia del comunismo en las masas trabajadoras", sin por ello abandonar la línea argumental centrada en las artimañas de las candidaturas burguesas para sustraer votos a Hidalgo (continuos anuncios radiales sobre el retiro de su postulación y entrega de sus fuerzas a Alessandri), además de la carencia completa de recursos económicos. El hidalguismo no se limitó a buscar en estos factores "la enorme deserción de los comunistas", también se refirió a la crisis interna del comunismo y a "la labor nefasta efectuada por directivas burocráticas y librescas", en clara referencia a sus rivales laferttistas. En contraste con el grupo oficialista, este sector reiteró que la campaña electoral había demostrado que la radicalización de las masas era un fenómeno totalmente independiente del partido si este desconocía "en forma sistemática las variaciones de la realidad". Los comunistas oposicionistas reconocían que Ibáñez había destruido las organizaciones revolucionarias de masas y debilitado al extremo las fuerzas del partido, cortando en la práctica sus lazos con las masas y su influencia sobre ellas al destruir sus medios de contacto $^{114}$.

\section{CONCLUSIONES}

Vista de manera aislada, la campaña presidencial de 1931 fue un suceso menor en la vida del comunismo chileno. Es probable que en ello resida la explicación sobre la nula o exigua atención prestada a este hecho por historiadores y memorialistas. No obstante, esta coyuntura de no más de un par de meses de duración - desde comienzos de agosto hasta comienzos de octubre- adquiere relevancia si se examina en la perspectiva del estudio de fenómenos de más vasto alcance como el impacto de las políticas del "tercer período" de la Internacional Comunista en Chile. Pese a que, a menudo, estas políticas son analiza-

\footnotetext{
${ }^{113}$ AHN, FMH, Informe del Comité Regional..., op. cit., fjs. 9-10, sin catalogar.

${ }^{114}$ En defensa de la revolución..., op. cit., p. 47.
} 
das a la luz de acontecimientos más violentos y de mayor visibilidad histórica -como la sublevación de la marinería o la "Pascua Trágica" de Copiapó y Vallenar ocurridos ese mismo año 1931 o el levantamiento mapuche y campesino del Alto Biobío terminado en masacre en 1934- las elecciones presidenciales a las que hemos hecho mención, constituyen, asimismo, una buena atalaya para observar los procesos de división en el seno del comunismo y el surgimiento de nuevas fuerzas de izquierda en este país.

La campaña presidencial de 1931 fue la primera ocasión en la que el cisma producido en el PCCh durante la dictadura de Carlos Ibáñez, teniendo como motivo principal la ruda intervención del SSA/BSA de la Internacional Comunista en los asuntos internos del partido chileno, emergió a la luz pública. La lucha, hasta entonces soterrada, entre sus fracciones, se reprodujo con toda su virulencia en el escenario público desde comienzos de agosto, amplificada por la competencia electoral entre los hermanos enemigos del comunismo chileno. Laferttistas e hidalguistas se disputaron los militantes, las estructuras partidarias, la influencia en las organizaciones sociales y los votos, con, a lo menos, igual fuerza y dureza que lo hicieron contra las candidaturas burguesas de Montero y Alessandri. Si los débiles lazos que unían ambas fracciones ya estaban rotos antes de la caída de la dictadura de Ibáñez, siendo muy poco probable que pudieran recomponerse, al fragor de la lucha electoral y por la contienda pública de la representación de la idea comunista, dichos lazos se destruyeron para siempre. Los mutuos agravios públicos sumados a la constante instigación del BSA a la facción de Elías Lafertte, Paulino González y Carlos Contreras Labarca para consumar y hacer irreversible la ruptura con el grupo de Manuel Hidalgo, Humberto Mendoza y Emilio Zapata, hicieron que en el segundo semestre de 1931 la reconciliación fuese objetivamente imposible, aun cuando, subjetivamente, algunos militantes de ambas fracciones hayan seguido alentando esa esperanza hasta comienzos de 1933.

La campaña presidencial puso de relieve las opuestas concepciones de frente único que animaban a las fracciones rivales del comunismo chileno a comienzos de la década de 1930. Si para los laferttistas este frente debía constituirse en forma exclusiva en la base obrera, sin llamamientos, pactos ni alianzas con otros partidos, grupos o tendencias, así fuesen estos en su esencia de cepa obrera y popular, de acuerdo con las políticas del "tercer período" que les dictaba el BSA desde Montevideo y supervisaban in situ sus emisarios, para los hidalguistas, en cambio, el "frente único obrero" no se limitaba a una construcción en la base social puesto que también incluía las alianzas y acuerdos con otros referentes como los emergentes grupos socialistas, laboristas y sectores del Partido Democrático. Hidalgo, sin dejar de reivindicar su condición de comunista, intentó proyectar una imagen de "candidato de las izquierdas", más acorde con una política de alianzas amplias en el campo popular.

Llama, pues, la atención que con dichas políticas los resultados electorales, magros para ambos candidatos comunistas, hayan sido aún más escuálidos para Hidalgo. Aunque los actores involucrados en esta competencia fratricida no intentaron examinar el hecho, limitándose a explicar la baja votación de sus respectivos candidatos por la acción de los enemigos burgueses y adjudicando también a sus excamaradas rivales una cuota de responsabilidad, es posible avanzar una disquisición tentativa a la luz de los antecedentes expuestos. 
El éxito relativo del laferttismo frente a la disidencia comunista se debió, en primer lugar, a su asociación con los elementos simbólicos del comunismo que estaban en el imaginario de los trabajadores que simpatizaban con sus ideas, en especial en los lugares de mayor influencia tradicional del partido (región del salitre y zona del carbón).

El control superestructural de la FOCH, así fuese esta "un cadáver glorioso", según los hidalguistas, vinculaba en la percepción de muchos obreros al bando oficialista del PCCh con un pasado glorioso (real o imaginario). La FOCH fue "resucitada" por esta fracción a la par que se desarrollaba la campaña presidencial, proyectándose una asociación clara entre el candidato Lafertte y la central sindical. No ocurría lo mismo con Hidalgo y sus partidarios que, empeñados en desarrollar una política sindical más flexible, consistente en acuerdos y convergencias con socialistas, anarquistas y sindicalistas sin partido, no poseían aún un referente sindical identificado con su corriente, ni siquiera en términos distintos a los de sus oponentes comunistas. El trabajo sindical del hidalguismo era aún demasiado embrionario como para traducirse en dividendos electorales y, aunque la debilidad del laferttismo en los sindicatos también era evidente, el peso de la tradición, de los símbolos y un nombre de prestigio -la FOCH- jugó a su favor.

La identificación sin matices del laferttismo con la Unión Soviética y la Internacional Comunista también debe haberlo favorecido, sobre todo si se considera que el Estado soviético no había sido afectado por la Gran Depresión Mundial, que su progreso económico era evidente y que en Chile recién empezaban a conocerse los efectos de la represión estalinista. El prestigio que el bolchevismo tenía en franjas de los trabajadores de este país beneficiaba en primer lugar a quienes aparecían más estrechamente asociados a la experiencia de la Revolución de Octubre. Si bien los hidalguistas reivindicaban con la misma fuerza su legado, al mismo tiempo que su pertenencia a la Internacional, en el segundo semestre de 1931 ya era de conocimiento público que los favores del organismo latinoamericano de la Komintern (BSA) recaían sobre la fracción de Lafertte y no sobre la de Hidalgo.

El apoyo político, simbólico y material del BSA fue otro factor que contribuyó a que la votación de Lafertte doblara la de Hidalgo. No obstante la consejería del emisario komintereano en Chile no fue un factor positivo puesto que su política puede ser resumida en la frase "solos contra todos", no es menos cierto que, como ya está dicho, la asociación simbólica del laferttismo con la representación de la Internacional en América del Sur y el apoyo financiero de esta a "su partido" chileno, dieron a la candidatura del comunismo oficialista una ventaja que los disidentes no pudieron contrarrestar.

Un último elemento que conviene destacar, se relaciona con el grado de profundidad con que habían penetrado las políticas del "tercer período" en el PCCh oficial. Aunque este sector del comunismo chileno se había impregnado de la retórica de "clase contra clase" y del imaginario del inminente colapso del capitalismo y del advenimiento de la revolución mundial, lo que se manifestaba en políticas sectarias, "izquierdistas" y aventureras (reflejadas con nitidez a propósito de la insurrección de la Escuadra), no es menos cierto que a pesar de ello y de su próximo reniego del legado político de Recabarren (formalizado en la Conferencia Nacional de julio de 1933), aún quedaba en el laferttismo un fondo político y cultural característico del "recabarrenismo", proclive a las alianzas y pactos electorales. Si 1931 marcó el paroxismo de la política de "clase contra 
clase" en el seno del PCCh, cuestión que se evidenció en la campaña electoral, muy pronto -hacia 1932-1933- se insinuarían los primeras tentativas -todavía torpes y poco consistentes- por implementar políticas de alianzas más vastas que las del mero "frente único por la base". Los porfiados hechos -sucesivos fracasos y aislamiento del partidomás el residuo de la tradición "recabarreana" contribuirían a esta tímida reformulación, facilitando con posterioridad el giro en $180^{\circ}$-de una política sectaria y aislacionistas a una de amplias alianzas, incluso con fuerzas burguesas- que a partir de 1935 empezaría a poner en práctica el PCCh por indicación de la Internacional Comunista.

El hidalguismo fracasaría en su intento por detentar la representación del comunismo en Chile. Tampoco sería capaz de persistir en un proyecto propio puesto que, a pesar de su transformación en Izquierda Comunista a partir de 1933, acompañada de un acercamiento a la corriente trotskista internacional, el grueso de sus dirigentes y militantes terminaría incorporándose a mediados de la misma década al recién fundado Partido Socialista de Chile. A pesar de lo anterior, cabe señalar que su breve trayectoria como sector diferenciado del comunismo chileno fue un capital político que permitió la convergencia con otras corrientes de izquierda que, reivindicando el marxismo como método de interpretación de la realidad social, pretendían levantar un referente autónomo de las internacionales que se disputaban la representación del movimiento obrero mundial.

No obstante, esa historia por venir aún no empezaba a construirse en 1931. La campaña presidencial fue solo un hito hacia el desenlace del enfrentamiento de las fracciones comunistas producido por la imposición de las políticas del "tercer período" por parte de la Komintern a "su partido" chileno. 